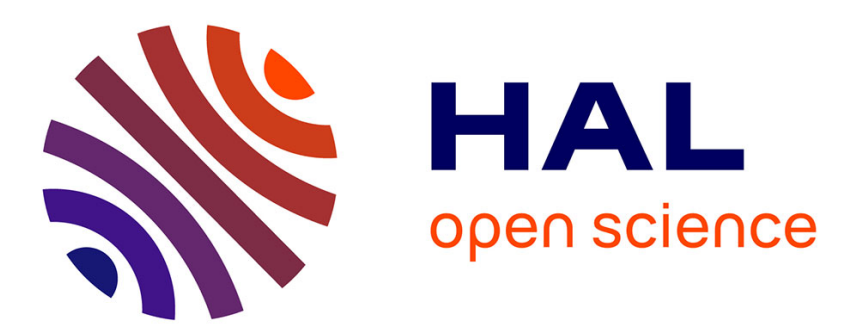

\title{
A distributed continuous simulation model to identify critical source areas of phosphorus at the catchment scale: model description
}

B. K. Koo, S. M. Dunn, R. C. Ferrier

\section{> To cite this version:}

B. K. Koo, S. M. Dunn, R. C. Ferrier. A distributed continuous simulation model to identify critical source areas of phosphorus at the catchment scale: model description. Hydrology and Earth System Sciences Discussions, 2005, 2 (4), pp.1359-1404. hal-00298689

\section{HAL Id: hal-00298689 \\ https://hal.science/hal-00298689}

Submitted on 3 Aug 2005

HAL is a multi-disciplinary open access archive for the deposit and dissemination of scientific research documents, whether they are published or not. The documents may come from teaching and research institutions in France or abroad, or from public or private research centers.
L'archive ouverte pluridisciplinaire HAL, est destinée au dépôt et à la diffusion de documents scientifiques de niveau recherche, publiés ou non, émanant des établissements d'enseignement et de recherche français ou étrangers, des laboratoires publics ou privés. 
Hydrol. Earth Sys. Sci. Discuss., 2, 1359-1404, 2005 www.copernicus.org/EGU/hess/hessd/2/1359/

SRef-ID: 1812-2116/hessd/2005-2-1359

European Geosciences Union

\section{A distributed continuous simulation model to identify critical source areas of phosphorus at the catchment scale: model description}

\section{B. K. Koo, S. M. Dunn, and R. C. Ferrier}

The Macaulay Institute, Craigiebuckler, Aberdeen AB15 8QH, UK

Received: 16 June 2005 - Accepted: 11 July 2005 - Published: 3 August 2005

Correspondence to: B. K. Koo (b.koo@macaulay.ac.uk)

(C) 2005 Author(s). This work is licensed under a Creative Commons License.

Title Page

Abstract Introduction

Conclusions References

Tables Figures

14

4

Back
Print Version

Interactive Discussion 


\section{Abstract}

This paper presents CAMEL (Chemicals from Agricultural Management and Erosion Losses), a distributed continuous simulation model to simulate daily phosphorus ( $P$ ) transformations and transport at the catchment scale. CAMEL is a process-oriented 5 mass-balance model that is based on both analytical and numerical approaches. In the model, a catchment is represented using a network of square grid cells each of which is comprised of various storages of water, sediment and P. Most of hydrological processes, soil erosion, sediment transport, and $\mathrm{P}$ transformations and transport are described using process-based equations. The $\mathrm{P}$ transformations between five $\mathrm{P}$ storages (active organic, stable organic, labile, active inorganic, and stable organic) are described using first-order kinetic equations. A comprehensive cascade routing scheme is used to simulate $P$ retention and transport along the channel system. Dissolved $P$ is also transported by groundwater flows, described using a two-dimensional Boussinesq equation. CAMEL simulates both surface and subsurface processes explicitly 15 and therefore is suitable for catchment-scale applications. The distributed, processoriented structure of CAMEL enables the model to be used for identifying critical source areas of $\mathrm{P}$ at the catchment-scale. CAMEL is also computationally efficient, allowing for long-term scale applications.

\section{Introduction}

20 The mechanism of phosphorus $(P)$ loss from agricultural land to watercourses involves a series of $\mathrm{P}$ transformation and transport processes. $\mathrm{P}$ transformations in the soil include decomposition and mineralisation of organic $P$, immobilisation of labile $P$ and sorption of labile $\mathrm{P}$ to/from sediment particles. $\mathrm{P}$ dissolved in soil water and $\mathrm{P}$ adsorbed to sediment particles can be transported to water bodies by a range of different sursediment transport because $P$ is readily adsorbed to sediment particles. $P$ is most

HESSD

$2,1359-1404,2005$

\section{A distributed continuous simulation model}

B. K. Koo et al.

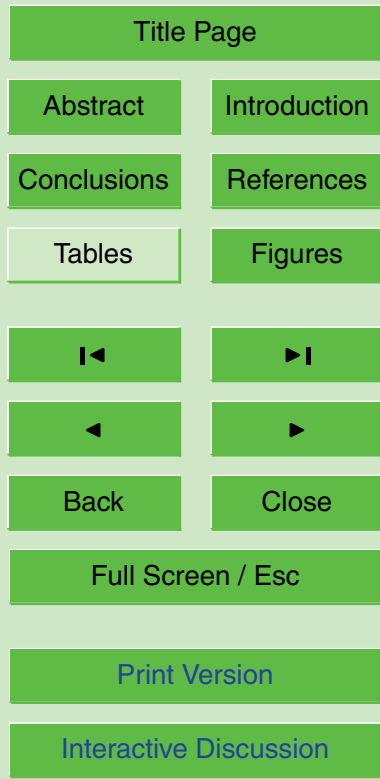

EGU 
commonly assumed to be transported predominantly in particulate forms through soil erosion by surface runoff (Walling et al., 1997; Bowes et al., 2003). However, where soil erosion is limited (e.g. as a result of high surface roughness associated with permanent vegetation cover), the majority of $P$ transported by surface runoff may be in dissolved 5 forms (Haygarth and Jarvis, 1997; Heathwaite and Dils, 2000). While surface runoff is an important pathway of $\mathrm{P}$ transport, its occurrence is highly variable both in time and space. It has been assumed commonly that $P$ loss through subsurface pathways is small. This may be true for matrix flow as it is unlikely to initiate significant $P$ transport (Heathwaite et al., 2000), However recent studies have reported that preferential flows, 10 through soil macropores or field drains, can be major pathways of $P$ in both particulate and dissolved forms (Gupta et al., 1999; Heathwaite and Dils, 2000; Simard et al., 2000; Chapman et al., 2001; Gardner et al., 2002). In particular, field drains are evidently effective conduits for $P$ export from agricultural catchments (Dils and Heathwaite, 1999). Also, a significant amount of $P$ adsorbed onto colloidal material from slurry or 15 livestock faeces can rapidly move through soil macro-pores (McGechan et al., 2002; McGechan, 2002). Within the river system, $P$ undergoes numerous transformation processes in the course of transport. Important processes related to $\mathrm{P}$ transformation within the river system include, amongst others, detachment and deposition of sediment particles, adsorption and desorption of soluble $\mathrm{P}$ to/from sediment particles both in suspension and in the river-bed (House et al., 1995). The combination of these processes, in tandem with variations in river flow and other environmental factors, makes the $P$ transport process very complicated.

The significance of each of the $P$ transformation and transport processes varies greatly in space. Thus a small fraction of the catchment area may contribute a large 25 proportion of the $\mathrm{P}$ load. These critical source areas (CSAs) are characterised by having high potential to release $P$ into surface or subsurface runoff in conjunction with hydrologic connectivity with streams (Needelman et al., 2001). Because of their high pollution potential, CSAs are of a major concern in catchment management. Gburek and Sharpley (1998) notes that specific P control measures implemented within a

HESSD

$2,1359-1404,2005$

\section{A distributed continuous simulation model}

B. K. Koo et al.

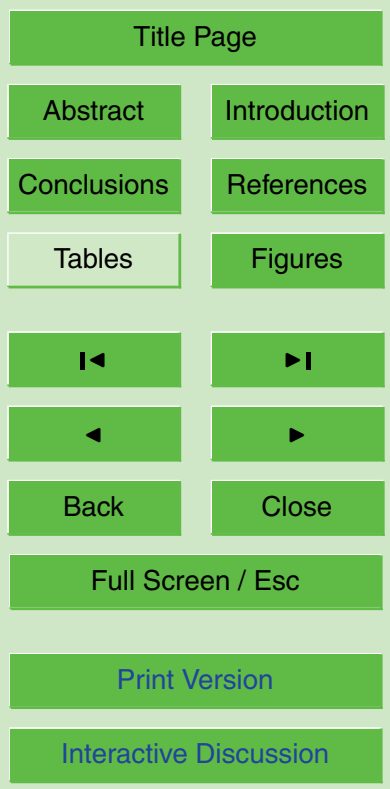

EGU 
comprehensive management strategy will reduce $\mathrm{P}$ losses most effectively only if they are targeted to CSAs. For effective catchment management, therefore, the location of CSAs and the major processes of $P$ transport mechanisms from CSAs, need to be identified.

5 A mathematical model can play a major role in identifying CSAs of $P$ provided the model structure is appropriate for that purpose. There are a number of continuous simulation models suggested for $\mathrm{P}$ transformation and transport processes at the catchment scale. These include HSPF (Bicknell et al., 1997), AnnAGNPS (Cronshey and Theurer, 1998; Theurer and Cronshey, 1998), ANSWERS-2000 (Bouraoui and Dil10 laha, 2000), SWRRB-WQ (Arnold et al., 1991), SWAT-2000 (Neitsch et al., 2001), ACRU2000 (Campbell et al., 2001), LASCAM (Viney et al., 2000) and INCA-P (Wade et al., 2002). However, most of these models have limitations in identifying CSAs of $P$. Some models divide a catchment into sub-catchments (e.g. AnnAGNPS, SWRRB-WQ and LASCAM) and others further divide sub-catchments into hydrologic response units 15 (HRUs) or something similar to HRUs (e.g. HSPF, SWAT-2000 and INCA-P). Models using subcatchments as calculation units usually have limitations in identifying CSAs due to their coarse spatial resolutions, although in theory subcatchments can be made as small as one wishes. In those models using HRUs, hydrologic and hydrochemical processes are calculated for individual HRUs, but the calculation results are aggregated to the subcatchment level. This means that HRUs are not connected to each other nor to the stream network and, therefore, transport processes within subcatchments are ignored. This is a somewhat severe limitation given the importance of the connectivity of a source area to the stream network in the transport of sediment-related pollutants, such as P. Moreover, both types of these models have a common problem with calcu25 lation units (subcatchments or HRUs) that are an irregular shape and of different sizes. The degree of aggregation for evaluating some parameters (e.g. mean slope of ground surface) varies with the shape and the size of calculation units, and, therefore, certain processes (e.g. sediment transport) cannot be evaluated in a consistent manner across the catchment. Because of these limitations, semi-distributed models may not

HESSD

$2,1359-1404,2005$

\section{A distributed continuous simulation model}

B. K. Koo et al.

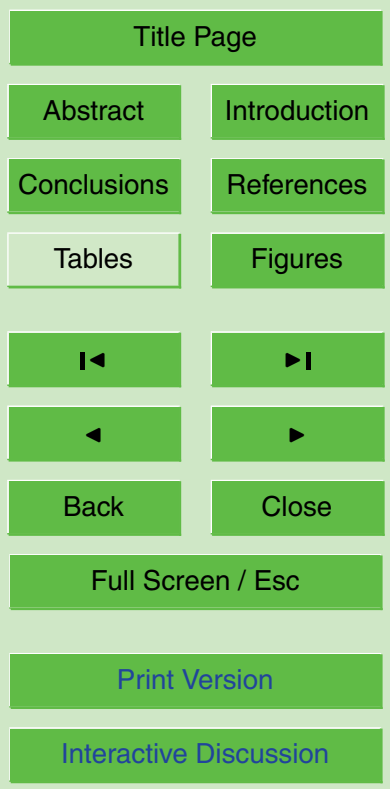

EGU 
be suitable for identifying CSAs.

In this sense, a distributed approach using square grid cells is more appropriate, but there are few distributed, continuous simulation models that simulate $\mathrm{P}$ transformation and transport processes at the catchment scale. ANSWERS-2000 and ACRU2000 are 5 such models that represent a catchment with a network of square grid cells. However, ANSWERS-2000 does not simulate some subsurface processes such as preferential flows through soil macropores and field drains. Therefore, the model may not be suitable for catchments where contribution of such subsurface flows to stream flow is significant. ACRU2000 estimates soil erosion using the modified USLE (Williams, 10 1975). This method does not adequately deal with soils where organic matter contents are greater than $4 \%$ (Lilly et al., 2002) and is therefore considered inappropriate for applications (such as in Scotland) where soils with high organic matter contents are common.

The perceived inadequacies of existing methods to address various catchment processes for identifying CSAs of $P$ in the context of Scottish environment have motivated the development of a new model CAMEL (Chemicals from Agricultural Management and Erosion Losses). This paper presents the theory of the model.

\section{Model overview}

CAMEL has been developed in an inter-disciplinary project that focused on long-term

catchment management in the context of the Water Framework Directive. At the design stage of CAMEL, requirements for the new model were identified in a broad sense:

- To simulate $\mathrm{P}$ transformation and transport processes at the catchment scale in the context of the Scottish environment;

- To identify critical source areas (CSAs) of P;

- To identify $P$ transport processes through surface and subsurface pathways;

HESSD

2, 1359-1404, 2005

\section{A distributed continuous simulation model}

B. K. Koo et al.

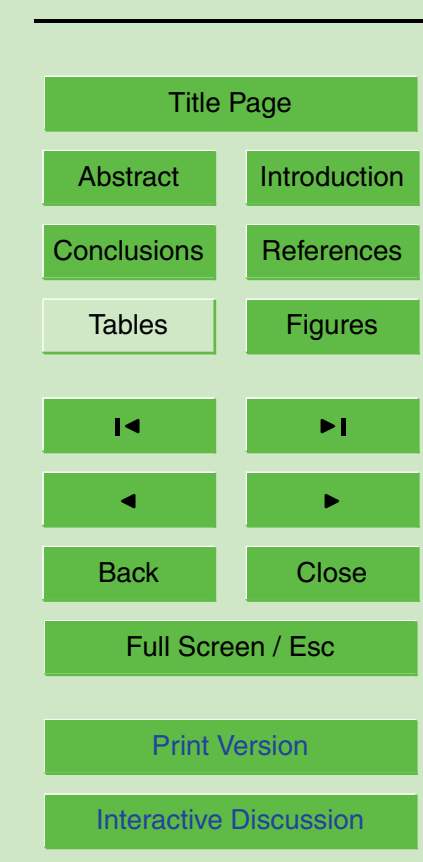

EGU 
- To analyse the long-term effect of land-use management on water quality;

HESSD

- To analyse the impact of climate changes on water quality.

2, 1359-1404, 2005

CAMEL represents hydrological and hydrochemical processes in a distributed manner using a network of square grid cells. The model simulates daily $P$ transformations 5 using process-oriented equations for each of the grid cells taking into account soil water content and temperature as well as agricultural practices. Transport processes of $P$ in both dissolved and particulate forms are simulated for surface runoff, preferential flows, groundwater flows and river channel flows.

In CAMEL, a grid cell can have a maximum of 8 neighbouring cells any number of which may act as upstream cells but with only one downstream drainage direction. Each of the grid cells represents the corresponding soil-aquifer column of the catchment and has a rectangular stream channel that runs in the middle bisecting the overland surface of the grid cell (Fig. 1). Both sides of the grid cell are inclined toward the channel at the mean slope of the ground surface.

In common with other distributed models, CAMEL requires rather extensive input data:

- Weather - rainfall, air temperature, dew-point temperature, cloud cover, wind speed and atmospheric pressure at daily time-steps;

- Topography - ground surface elevation, slope, flow direction, flow accumulation;

- Land cover - canopy storage capacity of rainfall interception, surface roughness, crop height, root depth, crop coefficient, leaf area index and litter index at each of the growth stages; soil cohesion increase by root reinforcement; livestock excretion rates for cattle and sheep; incorporation rate of plant residue; application rates of fertiliser and manure;

- Soil - depth; water contents at saturation, field capacity and wilting point, and residual water content; saturated hydraulic conductivity; fractions of sediment par-

\section{A distributed continuous simulation model}

B. K. Koo et al.

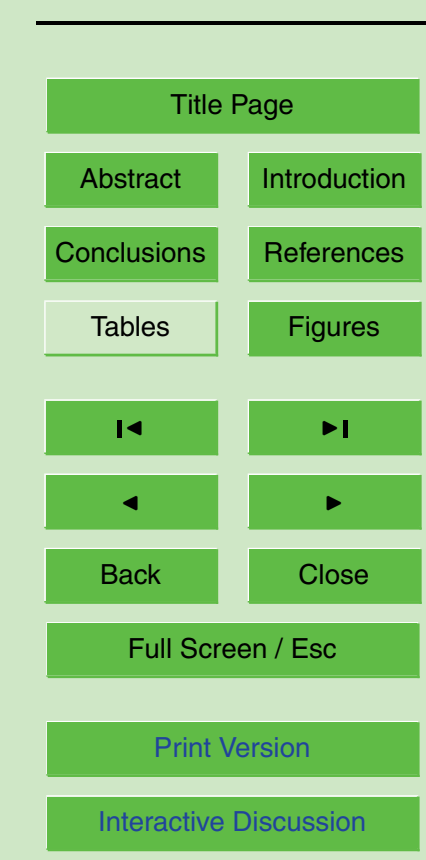

EGU 
ticle size classes, detachability and cohesion of the top soil; volume fraction of the interactive zone around macro pores; equilibrium coefficient for $\mathrm{P}$ adsorption;

- Aquifer - depth; water contents at saturation and field capacity, and residual water content; saturated hydraulic conductivity; equilibrium coefficient for $\mathrm{P}$ adsorption;

- Channel - channel width and depth; channel bed roughness;

The current version of CAMEL provides the following outputs:

- Time-series outputs for any grid cells within the catchment at every time-step;

- "Snapshot" outputs for the entire catchment at specific time-steps and cumulative snapshot outputs for the whole simulation period;

- Mass balance outputs of water, sediment and P for the entire catchment at every time-step.

CAMEL is written in an object-oriented language, VB.NET. The model structure is implemented so that each component of the model can be easily modified or extended.

\section{Hydrological processes}

15 For simulation of hydrological processes, CAMEL uses four water storages - canopy, soil, aquifer and channel (Fig. 2). The aquifer is divided into two layers - the upper layer and the lower layer representing fast-flowing and slow-flowing layers, respectively. Major hydrological processes in and between these storages are described below.

3.1. Rainfall Interception and evapotranspiration

20 When rain falls, a fraction of the rainfall is intercepted and stored in the vegetation canopy. The canopy storage capacity at a given time is assumed to be proportional

\section{A distributed continuous simulation model}

B. K. Koo et al.

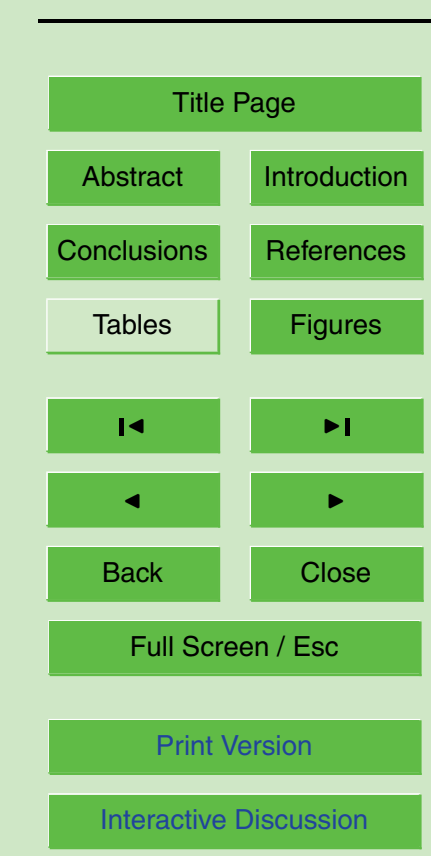

EGU 
to the leaf area index reflecting both seasonal variation of the vegetation canopy (i.e. growth and leaf fall) and agricultural practices (e.g. harvest). Through-fall, i.e. the rainfall that reaches the soil surface, is then estimated by subtracting the amount of rainfall interception from the amount of rainfall.

$5 \quad$ For the estimation of potential evaporation and reference crop transpiration, CAMEL uses two derivatives of the Penman equation suggested by Shuttleworth (1993):

$E_{p}=\frac{\delta\left(R_{n}+A_{h}\right)}{\delta+\gamma}+\frac{\gamma}{\delta+\gamma} \cdot \frac{6.43\left(1+0.536 U_{2}\right) D}{\lambda}$

$E_{r c}=\frac{\delta\left(R_{n}-G\right)}{\delta+\gamma\left(1+0.33 U_{2}\right)}+\frac{\gamma}{\delta+\gamma\left(1+0.33 U_{2}\right)} \cdot \frac{900}{T+275} U_{2} D$

where $E_{p}$ is potential evaporation rate $\left(\mathrm{mm}^{\text {day }}{ }^{-1}\right), E_{r c}$ is reference crop transpira10 tion rate $\left(\mathrm{mm}\right.$ day $\left.{ }^{-1}\right), R_{n}$ is net radiation exchange for the free water surface (MJ m${ }^{-2}$ day $\left.^{-1}\right), A_{h}$ is energy advected to the water body $\left(\mathrm{MJ} \mathrm{m}^{-2}\right.$ day $\left.^{-1}\right)$ which is ignored in the model, $\delta$ is gradient of saturated vapour pressure over temperature $\left(\mathrm{kPa}^{\circ} \mathrm{C}^{-1}\right), \gamma$ is psychrometric constant $\left(\mathrm{kPa}{ }^{\circ} \mathrm{C}^{-1}\right), U_{2}$ is wind speed measured at $2 \mathrm{~m}$ above the ground surface $\left(\mathrm{m} \mathrm{s}^{-1}\right), D$ is vapour pressure deficit $(\mathrm{kPa}), \lambda$ is latent heat of vapori15 sation of water $\left(\mathrm{MJ} \mathrm{kg}^{-1}\right), G$ is heat conduction into the soil $\left(\mathrm{MJ} \mathrm{m}^{-2}\right.$ day $\left.^{-1}\right)$, and $T$ is daily mean air temperature $\left({ }^{\circ} \mathrm{C}\right)$.

Direct evaporation from the canopy is assumed to take place at the rate of potential evaporation prior to transpiration process. The transpiration rate of a crop is estimated from $E_{r c}$ considering the crop coefficient and soil water stress factor as the following:

$20 E_{c}=k_{\psi} K_{c o} E_{r c}$

where $E_{c}$ is transpiration rate of a crop $\left(\mathrm{mm} \mathrm{day}^{-1}\right), k_{\psi}$ is soil water stress factor and $K_{c o}$ is potential crop coefficient. The soil water stress factor, $k_{\psi}$, is 1.0 when soil water content is greater than the field capacity, but when soil water content falls below the

HESSD

2, 1359-1404, 2005

\section{A distributed continuous simulation model}

B. K. Koo et al.

\section{Title Page}

Abstract Introduction

Conclusions References

Tables Figures

14

$$
4
$$

Back

Close

Full Screen / Esc

Print Version

Interactive Discussion

EGU 
field capacity, $k_{\psi}$ linearly decreases to zero as soil water content reaches the wilting point.

When the leaf area index of a crop is below 1.0, evaporation from the bare soil takes place. The evaporation from the soil surface, $E_{s}$, is estimated on an assumption that ${ }_{5} E_{s}$ is proportional to $E_{p}$ and to a power function of the effective soil saturation:

$E_{s}=\left\{\begin{array}{cl}0 & \text { (if } L A I \geq 1) \\ E_{p}(1-L A I)\left(\frac{\theta-\theta_{r e s}}{\theta_{\text {sat }}-\theta_{\text {res }}}\right)^{m} & \text { (if } L A I<1)\end{array}\right.$

where $E_{s}$ is evaporation from the soil surface $\left(\mathrm{mm}\right.$ day $\left.{ }^{-1}\right), L A l$ is leaf area index $\left(\mathrm{m}^{2}\right.$ $\left.\mathrm{m}^{-2}\right), \theta$ is soil water content $\left(\mathrm{m}^{3} \mathrm{~m}^{-3}\right)$ at a given time, $\theta_{\text {sat }}$ is saturated soil water content $\left(\mathrm{m}^{3} \mathrm{~m}^{-3}\right)$, and $\theta_{\text {res }}$ is residual soil water content $\left(\mathrm{m}^{3} \mathrm{~m}^{-3}\right), m$ is soil evaporation coefficient.

\subsection{Infiltration, saturation and surface runoff}

Infiltration of rainfall is represented in CAMEL using the Green-Ampt model (Green and Ampt, 1911) modified by Mein and Larson (1973):

$f=1000 k_{e f f}\left[1+\frac{S_{f}\left(\theta_{\text {sat }}-\theta\right)}{F}\right]$

15 where, $f$ is maximum infiltration rate $\left(\mathrm{mm} \mathrm{h}^{-1}\right), k_{\text {eff }}$ is effective hydraulic conductivity $\left(\mathrm{m} \mathrm{h}^{-1}\right), S_{f}$ is matric potential of suction at the wetting front $(\mathrm{mm})$, and $F$ is accumulated infiltration $(\mathrm{mm})$. When the rainfall intensity is less than the maximum infiltration rate, all rainfall infiltrates into the soil. When the rainfall intensity is greater than the maximum infiltration rate, a numerical method is used to calculate the accumulated infiltration: $f$ in Eq. (5) is replaced with $d F / d t$ and the integrated finite-difference form of Eq. (5) is iteratively solved for $F$ using a successive substitution approach. Here, for minimising numerical errors, the accumulated infiltration is estimated using daily mean hourly

HESSD

2, 1359-1404, 2005

\section{A distributed continuous simulation model}

B. K. Koo et al. 
rainfall intensity. Any excess of the daily rainfall above the accumulated infiltration contributes to the infiltration-excess surface runoff. When the soil-aquifer column is entirely saturated, the infiltration rate becomes zero and any further rainfall contributes to the infiltration-excess surface runoff. If the soil-aquifer column is fully saturated because of 5 the groundwater table rise, saturation-excess surface runoff is generated.

Surface runoff flows to the stream channel via a rill system. Based on the study of Gilley et al. (1990), it is assumed that one rill exists within every one-metre-wide section of ground surface sloping down to the stream channel. So, an array of rills meets the stream channel at a right angle on both sides of the stream channel. Rill flow rate is 10 assumed to be the same in each rill and the width of rill flows is estimated using a power function of the flow rate as suggested by Gilley et al. (1990):

$W_{r}=1.13 q_{r}^{0.303}$

where, $W_{r}$ is width of rill flows $(\mathrm{m})$ and $q_{r}$ is flow rate in a rill $\left(\mathrm{m}^{3} \mathrm{~s}^{-1}\right)$. Note in Eq. (6) that rill flow rate varies over time and, consequently, the rill flow width changes over time. Using the estimated width of rill flow, the rill flow velocity is estimated using the Manning's equation. The model ignores inter-rill flows assuming that all inter-rill flow is drained to the rill system within a daily time-step.

\subsection{Preferential flow}

In CAMEL, when soil water content exceeds the field capacity, the bottom of the soil layer is assumed to be saturated while the upper part remains at field capacity. This partial saturation creates a perched water table if the genuine groundwater table is not within the soil layer. Whether perched or genuine, if the elevation of the water table is higher than the channel bed, preferential flow through soil macropores is initiated as a Darcian flow. It is assumed that macropores develop only in vegetation-covered areas

\section{A distributed continuous simulation model}

B. K. Koo et al.

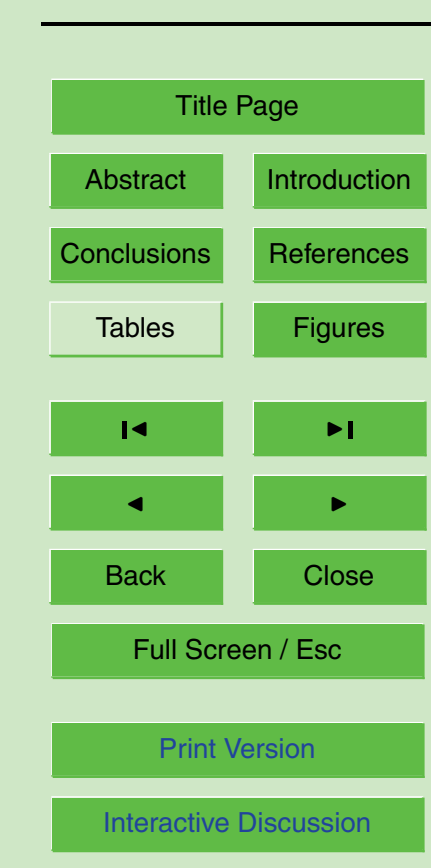

EGU 
conductivity times a macroporosity factor:

$k_{\text {eff }}=k_{\text {sat }} \cdot A$

HESSD

where $k_{\text {eff }}$ and $k_{\text {sat }}$ are effective and saturated hydraulic conductivity of the soil ( $\mathrm{m}$ day $^{-1}$ ), respectively, and $A$ is the macroporosity factor. The macroporosity factor is 5 estimated for undisturbed soils (Rawls et al., 1989):

$A=\exp \left(2.82-0.099 S \%+1.94 \delta_{b}\right)$

and for disturbed soils (Brakensiek and Rawls, 1988):

$A=\exp \left(0.96-0.032 S \%+0.04 C \%-0.032 \delta_{b}\right)$

2, 1359-1404, 2005

where $S \%$ and $C \%$ are volume percent of sand and clay (\%), respectively, and $\delta_{b}$ 10 is bulk density of the soil $\left(\mathrm{g} \mathrm{cm}^{-3}\right)$. The maximum value of macroporosity factor is restricted to 18 as suggested by Rawls et al. (1989) and it is assumed that uncovered areas have no macropores (i.e. $A=1$ ).

Another form of preferential flow represented in the model is field drainage. In many agricultural fields in the UK, field drains have been installed to lower the water table in 15 the soil. In such systems, field drains transport soil water directly to the stream channel. If the water table is above the drain tiles, drain flow is initiated. Estimation of the field drain flow is based on the drainage equation by Hooghoudt (1940):

$Q_{f d}=\frac{4 k_{e f f} \Delta h\left(2 d_{e q}+\Delta h\right)}{\Delta l^{2}} \Delta x^{2}$

where $Q_{f d}$ is preferential flow through field drains $\left(\mathrm{m}^{3}\right.$ day $\left.^{-1}\right), d_{e q}$ is equivalent depth ${ }_{20}(\mathrm{~m}), \Delta x$ is cell size $(\mathrm{m})$, and $\Delta /$ is field drain spacing $(\mathrm{m})$.

3.4. Aquifer recharge

Aquifer recharge in the model occurs only when soil water content is higher than the field capacity. The amount of water flowing through the soil layer to the aquifer is 1369

\section{A distributed continuous simulation model}

B. K. Koo et al.

\section{Title Page}

Abstract Introduction

Conclusions References

Tables Figures

14

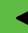

Back

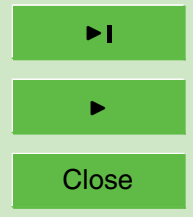

Full Screen / Esc

Print Version

Interactive Discussion

EGU 
estimated using a storage routing method similar to that in SWAT-2000 (Neitsch et al., 2001). For taking into account the effect of varying unsaturated hydraulic conductivity, calculations are carried out for individual $0.1 \%$ slices of soil water content above the field capacity:

${ }_{5} \quad q_{s a}=0.001 \cdot V_{s s}\left[1-\exp \left(-\Delta t / t_{T}\right)\right]$

where $q_{s a}$ is amount of water flow from the soil to the aquifer $\left(\mathrm{m}^{3}\right)$ calculated for individual $0.1 \%$ soil water content, $V_{S S}$ is volume of the soil layer $\left(\mathrm{m}^{3}\right), \Delta t$ is time step (day), and $t_{T}$ is travel time of the recharge flow (day). Here, $t_{T}$ is evaluated by dividing mean flow distance by unsaturated hydraulic conductivity (Eq. 12) that is estimated using the 10 Averjanov equation (Averjanov, 1950) (Eq. 13):

$t_{T}=\frac{1}{2} \frac{d_{\text {soil }}}{k_{\text {unsat }}}$

$k_{\text {unsat }}=k_{\text {sat }}\left(\frac{\theta-\theta_{\text {res }}}{\theta_{\text {sat }}-\theta_{\text {res }}}\right)^{n}$

where $d_{\text {soil }}$ is depth of the soil layer $(\mathrm{m}), k_{\text {unsat }}$ is unsaturated hydraulic conductivity of the soil layer ( $\mathrm{m} \mathrm{day}^{-1}$ ), and $n$ is Averjanov's exponent. Estimation of $q_{s a}$ using Eq. (11) 15 is repeated for each $0.1 \%$ slice of soil water content above the field capacity and all $q_{s a}$ are added together to give the total amount. The total amount of water flow from the soil to the aquifer is then limited by the percolation rate of the aquifer:

$Q_{s a}=\min \left(\frac{\sum q_{s a}}{\Delta t}, K_{s a t} \Delta x^{2}\right)$

where $Q_{s a}$ is total water flow from the soil to the aquifer $\left(\mathrm{m}^{3}\right.$ day $\left.^{-1}\right)$ and $K_{\text {sat }}$ is saturated 20 hydraulic conductivity of the fast-flowing aquifer layer $\left(\mathrm{m} \mathrm{day}^{-1}\right)$. Also, groundwater recharge flux within an aquifer column is estimated using an approach similar to the presented above.

HESSD

2, 1359-1404, 2005

\section{A distributed continuous simulation model}

B. K. Koo et al.

\section{Title Page}

\section{Abstract}

Introduction

Conclusions

References

Tables

Figures

14

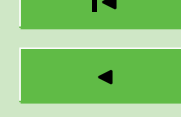

$\rightarrow 1$

Back

Close

\section{Full Screen / Esc}

Print Version

Interactive Discussion

\section{EGU}




\subsection{Channel routing}

HESSD

For routing of the channel water, the spatially distributed unit hydrograph approach proposed by Maidment (1993) was adopted in CAMEL with modifications. Based on an assumption that mean flow velocity is spatially variable but time- and discharge5 invariant, isochrones of the flow travel time to the catchment outlet are determined for each of the grid cells. The amount of channel water leaving a given isochrone area in a time step (ordinates of a unit hydrograph) constitutes a unit hydrograph at the catchment outlet. Individual unit hydrograph ordinates from each of the isochrone areas are then linearly superposed to give total discharge at the catchment outlet (Fig. 3). The mean flow velocity for each grid cell is estimated using the Manning's equation with the mean channel water depth that is specified by the user as a fraction of the channel width based on the observed flow data. It should be noted that the mean flow velocity estimated this way is used solely for calculating the mean travel time of channel water flow and that the real flow velocity is estimated at every time step using the results of channel routing. By applying this procedure not only to the catchment outlet but also to all other grid cells, channel discharge variables are estimated at every grid cell within the catchment. This approach may not be appropriate for simulating propagation of flood waves at a fine resolution of time, but it is considered to be reasonably accurate for daily time-step simulations.

\subsection{Aquifer-channel interaction}

The aquifer interacts with the stream channel through the channel bed whenever there is a difference in water heads between the groundwater table and the channel water level. When the groundwater table is higher than the channel water level, groundwater flows into the channel, and vice versa. Both flows are assumed to be Darcian flows and

aquifer layer.
2, 1359-1404, 2005

\section{A distributed continuous simulation model}

B. K. Koo et al.

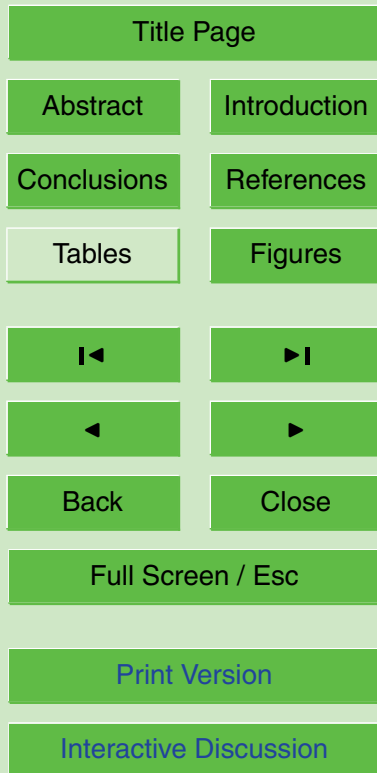

EGU 
In the model, groundwater flows are described as horizontal flows between grid cells and the vertical flow component is ignored. Based on the widely-used assumption that groundwater flow follows the Darcian law, the groundwater flow is described by the 5 following two-dimensional Boussinesq equation:

$S \frac{\partial h}{\partial t}=\frac{\partial}{\partial x}\left(K_{s a t} H \frac{\partial h}{\partial x}\right)+\frac{\partial}{\partial y}\left(K_{s a t} H \frac{\partial h}{\partial y}\right)$

where $S$ is the storage coefficient of the aquifer $\left(\mathrm{m} \mathrm{m}^{-1}\right), t$ is time (day), $h$ is elevation of groundwater table $(\mathrm{m})$, and $H$ is saturated thickness of the aquifer $(\mathrm{m})$. Expanding the terms in Eq. (15) to finite-difference analogues gives a non-linear equation for 10 each of the grid cells with groundwater table elevation, $h$, as the dependent variable. The system of equations for all grid cells is then solved iteratively using a successive over-relaxation method. This approach is valid providing the groundwater flow velocity $\left(=K_{\text {sat }} \Delta h \Delta x^{-1}\right)$ is less than the grid cell size divided by a daily time-step $\left(\Delta x\right.$ day $\left.^{-1}\right)$.

\section{Soil erosion and transport processes}

15 Sediment erosion and transport processes take place both on the land and within the channel. Equations for the soil erosion and transport component of CAMEL have been largely taken from the EUROSEM model (Morgan et al., 1998). For simulating the effect of sediment supply, an approach based on the sediment transport capacity is applied using two sediment storages - overland sediment storage and channel sediment storage (Fig. 4). Each of these storages consists of four sub-storages of clay, silt, fine sand and coarse sand. For simplicity, a representative value of particle size (effective diameters) is used for each of the particle size classes: $1 \mu \mathrm{m}$ for clay; $10 \mu \mathrm{m}$ for silt; $100 \mu \mathrm{m}$ for fine sand; and $1000 \mu \mathrm{m}$ for coarse sand.

\section{A distributed continuous simulation model}

B. K. Koo et al.

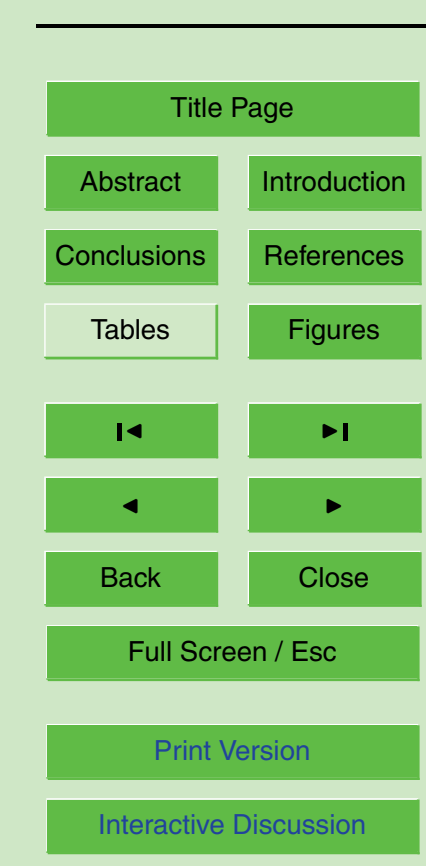

EGU 
During a rainfall event, sediment particles on the soil surface are detached by raindrop impacts. This splash detachment by rain drops is related to the kinetic energy of rainfall and is estimated in CAMEL for both direct rainfall and leaf drainage from the canopy.

5 The kinetic energy of rainfall reaching the ground surface can be described by the following (Brandt, 1989, 1990):

$K E_{r}=\max (8.95+8.44 \log \iota, 0) \cdot R$

$K E_{l}=\max \left(15.8 \sqrt{H_{C}}-5.87,0\right) \cdot\left(R-I_{C}\right)$

where $K E_{r}$ is kinetic energy of direct rainfall $\left(\mathrm{J} \mathrm{m}^{-2}\right), K E_{l}$ is kinetic energy of leaf 10 drainage from the canopy $\left(\mathrm{J} \mathrm{m}^{-2}\right), \iota$ is rainfall intensity $\left(\mathrm{mm} \mathrm{h}^{-1}\right), R$ is daily rainfall $(\mathrm{mm}), I_{c}$ is canopy interception $(\mathrm{mm})$, and $H_{c}$ is canopy height $(\mathrm{m})$. Note that $K E_{\text {I }}$ in Eq. (17) becomes zero if the canopy height is less than $14 \mathrm{~cm}$. The total kinetic energy is estimated by taking into account the ground surface condition. The splash detachment is calculated for each of the particle size classes (Morgan et al., 1998) by:

$S D_{i}=10 \eta\left[K E_{r}\left(1-\lambda_{c}\right)+K E_{l} \lambda_{c}\right] \exp \left(-b d_{s w}\right) \varsigma_{i}$

where $S D$ is splash detachment by rain drop impact $\left(\mathrm{kg} \mathrm{ha}^{-1}\right), \eta$ is soil detachability index $\left(\mathrm{g} \mathrm{J}^{-1}\right), \lambda_{c}$ is a fraction of ground surface covered by plant canopy, $b$ is rain drop impact attenuation coefficient, $d_{s w}$ is depth of overland surface water $(\mathrm{mm}), \varsigma$ is fraction of a given particle size class in the top soil, and $i$ is subscript for particle size classes.

20 It is assumed that sediment particles mobilised by splash detachment constitute the initial sediment concentration in the surface runoff.

\subsection{Flow detachment}

Sediment detachment by rill flows is simulated according to the erosion-deposition theory proposed by Smith et al. (1995). The sediment concentration at the transport

\section{A distributed continuous simulation model}

B. K. Koo et al.

\section{Title Page}

Abstract Introduction

Conclusions References

Tables Figures

14

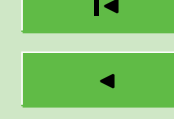

$>$ I

Back

Close

Full Screen / Esc

Print Version

Interactive Discussion 
capacity represents the sediment concentration at which the rate of erosion and the accompanying rate of deposition are in balance. The equation for sediment erosion and deposition during rill flow is expressed in terms of settling velocity and transport capacity (Smith et al., 1995):

$5 F D_{i}=\varepsilon_{d} v_{i}\left(T C_{i}-C_{i}\right) W_{r}$

where $F D$ is sediment detachment by the rill flow $\left(\mathrm{kg} \mathrm{m}^{-1} \mathrm{~s}^{-1}\right), \varepsilon_{d}$ is detachment efficiency coefficient, $v$ is settling velocity of sediment particles $\left(\mathrm{m} \mathrm{s}^{-1}\right), T C$ is sediment transport capacity of the rill flow $\left(\mathrm{kg} \mathrm{m}^{-3}\right)$, and $C$ is initial sediment concentration in the rill flow $\left(\mathrm{kg} \mathrm{m}^{-3}\right)$. The initial sediment concentration is estimated by dividing the 10 amount of splash detachment by the amount of surface runoff. The settling velocity of sediment particles is estimated using Stokes' law, assuming constant density and viscosity of water.

The sediment transport capacity of the rill flow at a given point is the maximum net erosion potential and is estimated as the following (Govers, 1990; Morgan et al., 1998):

${ }_{15} T C_{i}=\alpha_{i} \rho\left(\omega-\varpi_{i}\right)^{\beta_{i}}$

$\omega=s \cdot \bar{u}$

$\alpha_{i}=\left(\frac{\phi_{i}+5}{0.32}\right)^{-0.6}$

$\beta_{i}=\left(\frac{\phi_{i}+5}{300}\right)^{0.25}$

where $\alpha$ and $\beta$ are experimentally-determined coefficients, $\rho$ is density of sediment 20 particles $\left(=2650 \mathrm{~kg} \mathrm{~m}^{-3}\right), \omega$ is unit stream power $\left(\mathrm{cm} \mathrm{s}^{-1}\right), \varpi$ is critical value of unit stream power $\left(\mathrm{cm} \mathrm{s}^{-1}\right), s$ is energy slope of water, $\omega$ is mean flow velocity $\left(\mathrm{cm} \mathrm{s}^{-1}\right)$, and $\phi$ is median particle size $(\mu \mathrm{m})$. If the sediment transport capacity is greater than the

HESSD

$2,1359-1404,2005$

\section{A distributed continuous simulation model}

B. K. Koo et al.

\section{Title Page}

Abstract Introduction

Conclusions References

Tables Figures

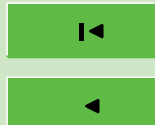

Back

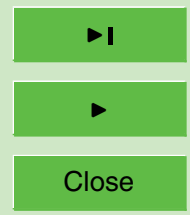

Full Screen / Esc

Print Version

Interactive Discussion

EGU 
initial sediment concentration, more sediment particles may be detached (flow detachment) and transported to the channel. If the sediment transport capacity is less than the initial sediment concentration, however, a part or all of the detached sediment may be deposited and added to the overland sediment storage. Govers (1990) introduced 5 the critical unit stream power, $\varpi$, and suggested a value of $0.4 \mathrm{~cm} \mathrm{~s}^{-1}$, but his study covers only a limited range of particle sizes from coarse silt to coarse sand. Therefore the suggested value may not be valid for clay and fine silt. In CAMEL, the value of $\varpi$ for each of the particle size classes can be adjusted by the user.

The detachment efficiency coefficient, $\varepsilon_{d}$, in Eq. (19) is used to represent the effect 10 of cohesive soil material on sediment detachment and is defined as a function of the cohesion of wet soil (Rauws and Govers, 1988):

$\varepsilon_{d}=\frac{1}{0.89+0.56 \zeta}$

where $\zeta$ is cohesion of wet soil $(\mathrm{kPa})$. By definition, $\varepsilon_{d}$ takes a value of 1 when the sediment transport capacity is less than the initial concentration (i.e. when net deposition 15 occurs).

\subsection{Sediment transport to the channel}

The amount of sediment transported to the channel by rill flow depends on the transport capacity of the rill flow and the overland sediment storage. When the transport capacity is greater than the initial concentration, flow detachment takes place but its amount is 20 limited to the overland sediment storage. If the transport capacity is less than the initial concentration, excess sediment is deposited on the land and no flow detachment takes place. The overland sediment storage thus represents the amount of disaggregated sediment particles on the ground surface. To reflect soil aggregation processes, the size of overland sediment storage is assumed to exponentially decrease over time.

25 Transport of sediment particles by preferential flows through soil macropores and field drains is not included in the model due to the complexity of the transport process.

\section{A distributed continuous simulation model}

B. K. Koo et al.

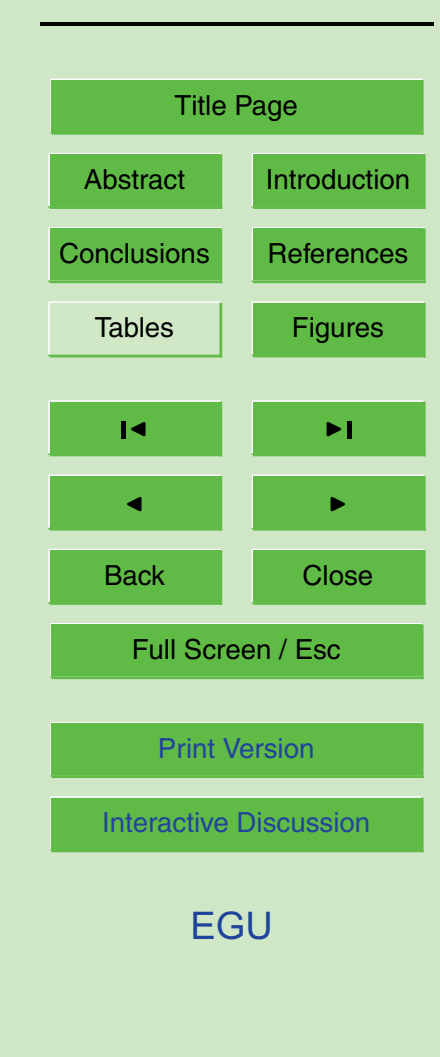


Sediment transported to the channel through the rill system is added to the channel sediment storage and is transported downstream by channel flows. A comprehensive cascade routing scheme has been developed to simulate sediment detachment 5 and deposition processes along the channel network. The channel sediment budgets are calculated first for first-order cells with no upstream cells. The amount of sediment leaving each of the first-order cells is then calculated and routed downstream cell by cell taking into account the isochrones in the course of the downstream transport. Sediment transport processes in the channel are estimated using the same erosiondeposition theory applied to the rill flow in Eq. (19), but the sediment cohesion effect is ignored $\left(\varepsilon_{d}=1\right)$ on the assumption that sediment particles on the channel bed are loose. As sediment transport processes are estimated for each of four particle size classes, the composition of the channel bed sediment may vary according to the transport capacity of the channel flow at a given time and space.

\section{5. P transformation processes}

$\mathrm{P}$ transformation processes in CAMEL are simulated for organic and inorganic $\mathrm{P}$ storages in the soil, aquifer and channel (Fig. 5). For simplification, organic $P$ storages in the aquifer and the channel are ignored. Organic $\mathrm{P}$ in the soil is divided into two storages: the active organic $\mathrm{P}$ storage $\left(P_{A O}\right)$ and the stable organic $\mathrm{P}$ storage $\left(P_{S O}\right)$. $P_{A O}$ consists of $\mathrm{P}$ in undecomposed plant residues, livestock excretion, manure and microbes, whereas $P_{S O}$ is composed of $\mathrm{P}$ in stable organic matter i.e. humus. Inorganic $\mathrm{P}$ is divided into labile $\mathrm{P}\left(P_{L B}\right)$, active inorganic $\mathrm{P}\left(P_{A l}\right)$ and stable inorganic $\mathrm{P}\left(P_{S I}\right)$ storages. $P_{L B}$ is in rapid equilibrium with $P_{A l}$ which in return is in slow equilibrium with $P_{S /}$. When inorganic fertiliser $\mathrm{P}$ is added, it rapidly equilibrates between $P_{L B}$ and $P_{A I}$. The
2, 1359-1404, 2005

\section{A distributed continuous simulation model}

B. K. Koo et al.

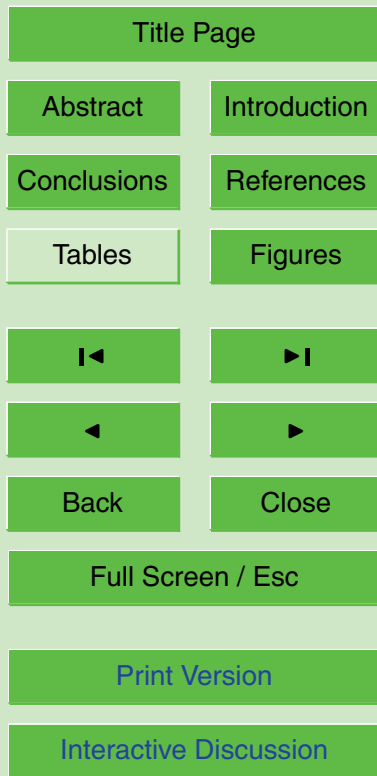

EGU 
are assumed and, therefore, $\mathrm{P}$ adsorption and desorption are the only transformation processes simulated in the model.

It is assumed that vertical distribution of $P$ in the soil reaches its maximum at the soil surface and exponentially decreases with depth. Unlike in the soil, $\mathrm{P}$ in the aquifer and 5 the channel is assumed to be completely mixed within each of the storages.

\section{1. $P$ transformations in the soil}

All $P$ transformation rates are estimated using first-order kinetic equations taking into account the effect of soil water content and temperature.

The decomposition rate of active organic matter is assumed to be constant, regard10 less of the fraction of fresh organic matter remaining since the last incorporation into the soil. It is also assumed that the decomposition rate is not limited by either the $\mathrm{C} / \mathrm{N}$ or $\mathrm{C} / \mathrm{P}$ ratio:

$\xi_{d}=k_{d} k_{T B} k_{\theta} P_{A O}$

where $\xi_{d}$ is active organic $\mathrm{P}$ decomposition rate $\left(\mathrm{kg}^{-\mathrm{P} \text { ha }}{ }^{-1}\right.$ day $\left.^{-1}\right), k_{d}$ is rate coefficient 15 for active organic matter decomposition $\left(\right.$ day $\left.^{-1}\right), k_{T B}$ is temperature adjustment factor for biochemical processes, $k_{\theta}$ is soil water adjustment factor, and $P_{A O}$ is active organic $\mathrm{P}$ in the soil $\left(\mathrm{kg}-\mathrm{P}\right.$ ha $\left.{ }^{-1}\right)$. When active organic $\mathrm{P}$ is decomposed, it is assumed that $80 \%$ of the decomposed $P$ undergoes mineralisation and the remaining $20 \%$ is incorporated into the stable organic $\mathrm{P}$ storage $\left(P_{S O}\right)$. So the total mineralisation rate of $\mathrm{P}$ is estimated as the following:

$\xi_{m}=0.8 \xi_{d}+k_{h} k_{T B} k_{\theta} P_{S O}$

where $\xi_{m}$ is $\mathrm{P}$ mineralisation rate $\left(\mathrm{kg}-\mathrm{P}\right.$ ha ${ }^{-1}$ day $\left.^{-1}\right), k_{h}$ is rate coefficient for humus mineralisation $\left(\right.$ day $\left.^{-1}\right), P_{S O}$ is stable organic $\mathrm{P}$ in the soil $\left(\mathrm{kg}^{-\mathrm{P}}\right.$ ha $\left.{ }^{-1}\right)$. Mineralised $\mathrm{P}$ is added to the labile $P$ storage and there is a reverse process that incorporates labile $P$ back to organic $P$. However, this immobilisation rate of $P$ is only a very small fraction of the decomposition rate (Jones et al., 1984) and therefore is ignored in the model.

HESSD

2, 1359-1404, 2005

\section{A distributed continuous simulation model}

B. K. Koo et al.

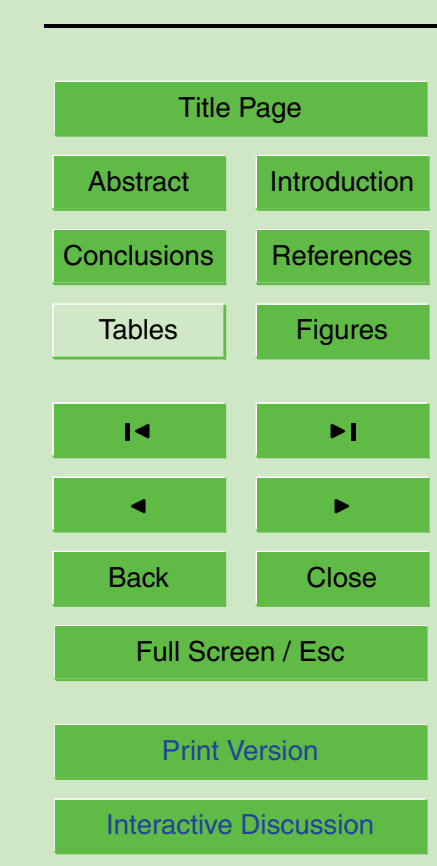

EGU 
Adsorption of $P$ from the solution to the surface of sediment particles is simulated in two separate processes. When a gradient of $\mathrm{P}$ concentrations exists between inorganic $\mathrm{P}$ storages, a rapid equilibrium is initially reached between $P_{L B}$ and $P_{A l}$ and then a subsequent slow reaction takes place between $P_{A /}$ and $P_{S /}$. The rapid adsorption rate of $P$ from the labile $P$ storage to the active inorganic $P$ storage is estimated using Eq. (27):

$\xi_{r a}=k_{r a} k_{T S} k_{\theta}\left(\sigma_{r a} P_{L B}-P_{A l}\right)$

where $\xi_{r a}$ is rapid adsorption rate of $\mathrm{P}$ from $P_{L B}$ to $P_{A l}\left(\mathrm{~kg}-\mathrm{P}\right.$ ha ${ }^{-1}$ day $\left.^{-1}\right), k_{r a}$ is rate coefficient for rapid adsorption of $\mathrm{P}$ from $P_{L B}$ to $P_{A I}\left(\right.$ day $\left.^{-1}\right), k_{T S}$ is temperature adjustment 10 factor for sorption (can exceed 1.0), $P_{L B}$ is labile $\mathrm{P}$ storage $\left(\mathrm{kg}-\mathrm{P}\right.$ ha $\left.{ }^{-1}\right), P_{A l}$ is active inorganic $\mathrm{P}$ storage $\left(\mathrm{kg}-\mathrm{P}\right.$ ha $\left.{ }^{-1}\right)$, and $\sigma_{r a}$ is equilibrium coefficient for rapid adsorption.

The slow adsorption rate of $P$ from the active inorganic $P$ storage to the stable inorganic $\mathrm{P}$ storage is estimated by assuming that $P_{S /}$ is four times larger than $P_{A l}$ in equilibrium:

$15 \xi_{s a}=k_{s a}\left(4 P_{A l}-P_{S I}\right)$

where $\xi_{s a}$ is slow adsorption rate of $\mathrm{P}$ from $P_{A l}$ to $P_{S I}\left(\mathrm{~kg}-\mathrm{P} \mathrm{ha}{ }^{-1}\right.$ day $\left.^{-1}\right), k_{s a}$ is rate coefficient for slow adsorption of $\mathrm{P}$ from $P_{A /}$ to $P_{S /}\left(\right.$ day $\left.^{-1}\right)$, and $P_{S /}$ is stable inorganic $P$ storage in the soil $\left(\mathrm{kg}-\mathrm{P} \mathrm{ha}^{-1}\right)$.

From the $P$ transformation processes defined in Eqs. (25) to (28), the changes in the five $\mathrm{P}$ storages are estimated at every time step using a fourth-order Runge-Kutta method for simultaneous solution of the equations.

HESSD

2, 1359-1404, 2005

\section{A distributed continuous simulation model}

B. K. Koo et al.

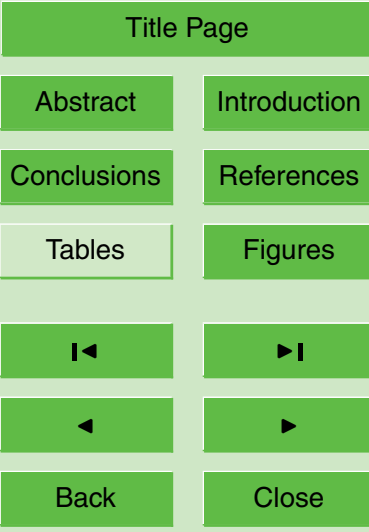

Full Screen / Esc

Print Version

Interactive Discussion 
Uptake of $\mathrm{P}$ (mainly in the form of $\mathrm{H}_{2} \mathrm{PO}_{4}^{-}$) by plant roots is assumed to follow Michaelis-

Menten kinetics (Barber, 1980) and is limited by soil water availability:

$P_{u p}=U_{\max } \mu \cdot \frac{C_{D P(r z)}}{M \mu+C_{D P(r z)}} \cdot k_{\psi}$

5 where $P_{u p}$ is $\mathrm{P}$ uptake rate by a given plant $\left(\mathrm{kg}-\mathrm{P}\right.$ ha ${ }^{-1}$ day $\left.^{-1}\right), U_{\max }$ is maximum rate of $\mathrm{P}$ uptake by the given plant $\left(\mathrm{kg}-\mathrm{P} \mathrm{ha}^{-1} \mathrm{day}^{-1}\right), \mu$ is a ratio of potential crop coefficient for a given day to the maximum crop coefficient $\left(=K_{c o} / K_{c o(\max )}\right), C_{D P(r z)}$ is concentration of dissolved $\mathrm{P}$ in the root zone $\left(\mathrm{kg}-\mathrm{P} \mathrm{m}{ }^{-3}\right)$, and $M$ is Michaelis-Menten's half-saturation constant of dissolved $\mathrm{P}$ concentration for the given plant $\left(\mathrm{kg}-\mathrm{P} \mathrm{m}^{-3}\right)$. Note in Eq. (29) 10 that $U_{\max }$ and $M$ are multiplied by $\mu$ to reflect the seasonal variation of crop growth and hence $\mathrm{P}$ demand. The soil water stress factor $\left(k_{\psi}\right)$ is applied to limit the $\mathrm{P}$ uptake rate according to soil water availability. There is no limitation when the soil water content exceeds the field capacity, but $\mathrm{P}$ uptake decreases linearly as the soil water content decreases from field capacity to wilting point and no uptake occurs when the soil water content is below the wilting point. Thus, Eq. (29) reflects both the $\mathrm{P}$ demand and availability in the root zone.

\subsection{Factors affecting $P$ transformations}

$P$ transformation processes in the model are affected by two environmental factors soil water content and soil temperature. The effect of soil water content on organic matter decomposition and mineralisation is estimated using a segmented linear function: the soil water adjustment factor $\left(k_{\theta}\right)$ is zero when there is no soil water, then increases linearly with soil water content to its maximum $(=1)$ when the soil water content is at field capacity. The maximum value is maintained until the soil water content is at the mid-point between field capacity and saturation and then decreases to 0.6 when the soil is fully saturated.

\section{A distributed continuous simulation model}

B. K. Koo et al.

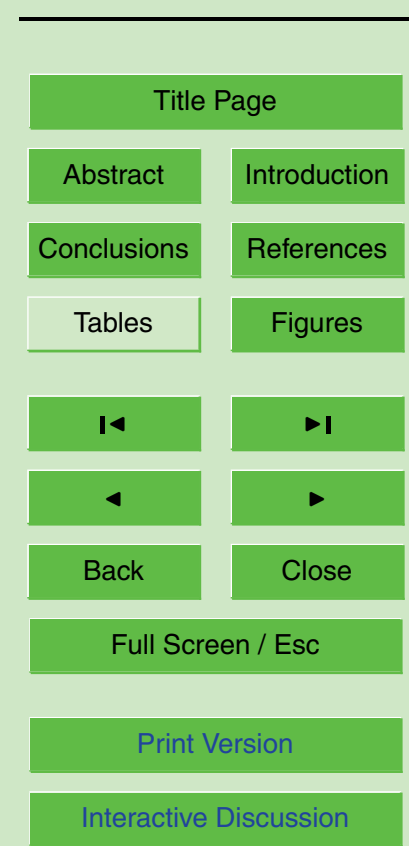

EGU 
Temperature influences the rates of all of the $\mathrm{P}$ transformation processes. The effect of temperature on rates of organic matter decomposition and mineralisation, which are driven by microbial activities, is estimated using the soil respiration rate equation proposed by Lloyd and Taylor (1994):

${ }_{5} k_{T B}=\exp \left(4.34-\frac{308.56}{T^{\prime}+46.02}\right)$

where $T^{\prime}$ is daily mean soil temperature $\left({ }^{\circ} \mathrm{C}\right)$. Another temperature adjustment factor is used to estimate the effect of temperature on $\mathrm{P}$ sorption (Jones et al., 1984):

$k_{T S}=\exp \left(0.115 T^{\prime}-2.88\right)$

Note that $k_{T B}$ and $k_{T S}$ are equal to unity when the soil temperature is $25{ }^{\circ} \mathrm{C}$.

10 To evaluate the temperature adjustment factors in Eqs. (30) and (31), the mean daily soil temperature is estimated using the approach of Kang et al. (2000) in which the effects of ground litter as well as leaves are accounted for:

$T_{t}^{\prime}=T_{t-1}^{\prime}+\left(T_{t}-T_{t-1}^{\prime}\right) \cdot \exp \left[-z\left(\frac{\pi}{k p}\right)^{1 / 2}\right] \cdot \exp \left(k_{e} L L_{t}\right)$

$L L_{t}=\left\{\begin{array}{cl}L A I_{t}+L I T_{t} & \left(\text { if } T_{t}>T_{t-1}^{\prime}\right. \\ L I T_{t} & \text { (if } T_{t} \leq T_{t-1}^{\prime}\end{array}\right)$

15 where $z$ is soil depth $(m), k$ is thermal diffusivity of the soil $\left(\mathrm{cm}^{2} \mathrm{~s}^{-1}\right), p$ is period of diurnal temperature variation $(=86400 \mathrm{~s}), k_{e}$ is extinction coefficient for solar radiation interception through the canopy, $L L$ is combined index of leaf area and ground litter $\left(\mathrm{m}^{2} \mathrm{~m}^{-2}\right), L I T$ is $L A$ / equivalent of ground litter $\left(\mathrm{m}^{2} \mathrm{~m}^{-2}\right)$, and $t$ and $t-1$ are subscripts for daily time-step (day). In the model, for simplicity, soil temperature at a fixed depth of $10 \mathrm{~cm}$ is estimated and used. Thermal diffusivity of soil varies in a range depending on the soil texture, organic matter and soil water content. However, according to Kang et al. (2000), soil temperature in Eq. (32) is not very sensitive to thermal diffusivity,

\section{A distributed continuous simulation model}

B. K. Koo et al.

\section{Title Page}

Abstract Introduction

Conclusions References

Tables Figures

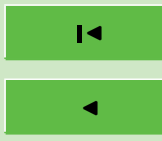

Back

Close

Full Screen / Esc

Print Version

Interactive Discussion

\section{0}


but is very sensitive to $L L$. The model uses a constant value for the extinction coefficient for solar radiation interception $\left(k_{e}=0.45\right)$ and for the thermal diffusivity of the soil $\left(k=5 \times 10^{-7} \mathrm{~m}^{2} \mathrm{~s}^{-1}\right)$.

\section{P transport processes}

5 In CAMEL, $\mathrm{P}$ transport processes are simulated for both sediment-bound $\mathrm{P}$ (particulate $P)$ and dissolved $P$. The amount of particulate $P$ transported with sediment particles is estimated using $P$ adsorption capacity of each of the sediment particle size classes and the transport of dissolved $P$ is estimated using a transfer function. Dissolved $P$ here refers to inorganic $P$ only and the transport of dissolved organic $P$ is not simulated in the model.

\subsection{Transport of particulate $\mathrm{P}$ by surface runoff}

For estimating transport of particulate $\mathrm{P}$ by surface runoff from overland to channel, it is assumed that only particulate $P$ in the top $1 \mathrm{~cm}$ of the soil can be transported. The amount of $P$ transported in particulate form by surface runoff is estimated for each particle size class using Eq. (34):

$P P_{s r}=S_{s r} \cdot C_{P P(t o p)} \cdot \varepsilon_{p}$

where $P P_{s r}$ is amount of particulate $P$ transported from the soil to the channel $(\mathrm{kg}-\mathrm{P}$ $\left.\mathrm{ha}^{-1}\right), S_{S r}$ is sediment transported to the channel by surface runoff $\left(\mathrm{kg} \mathrm{ha}^{-1}\right), C_{P P(t o p)}$ is concentration of particulate $P$ in the top $1 \mathrm{~cm}$ of the soil $\left(\mathrm{kg}^{\mathrm{P}} \mathrm{kg}{ }^{-1}\right)$, and $\varepsilon_{P}$ is 20 enrichment ratio of P. $C_{P P(t o p)}$ is estimated based on top soil texture, vertical distribution of $\mathrm{P}$, and $\mathrm{P}$ adsorption capacity of sediment particles. The enrichment ratio, $\varepsilon_{p}$, is defined as the concentration of $\mathrm{P}$ in the eroded sediment divided by the $\mathrm{P}$ concentration in the soil. The enrichment ratio of $\mathrm{P}$ in sediment decreases markedly with the amount

\section{A distributed continuous simulation model}

B. K. Koo et al.

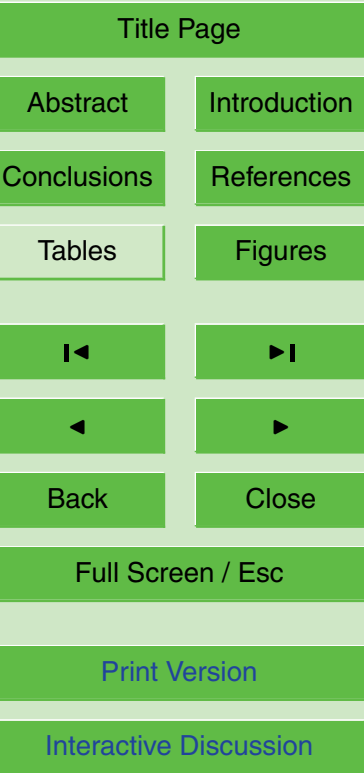

EGU 
of eroded sediment and a logarithmic relationship suggested by Menzel (1980) is used in the model:

$\varepsilon_{p}=\exp \left(2-0.2 \ln S_{s r}\right)$

Transport of particulate $\mathrm{P}$ by preferential flows through soil macropores and field drains 5 is ignored in the model.

\subsection{Transport of dissolved $P$ in the soil}

Dissolved $P$ is transported to the channel by surface runoff and preferential flows, and it is also transported to the aquifer by recharge flows. As surface runoff flows over the top soil, water interacts with the top soil, transporting some of the dissolved $P$ in pore waters. In the model, this process is conceptualised using a transfer function that estimates the proportion of dissolved $\mathrm{P}$ transported from the soil pore water to the channel by surface runoff. It is assumed that surface runoff interacts with the top $1 \mathrm{~cm}$ of the soil. The amount of dissolved $\mathrm{P}$ transported by surface runoff is estimated by the following:

$$
\begin{aligned}
& D P_{s r}=P_{L B(t o p)} \cdot \Pi_{s r} \\
& \Pi_{s r}=1-\exp \left(-\frac{Q_{s r}}{\Omega_{s r}}\right)
\end{aligned}
$$

where $D P_{s r}$ is amount of dissolved $\mathrm{P}$ transported from the top soil to the channel by surface runoff $\left(\mathrm{kg}-\mathrm{P}\right.$ ha $\left.{ }^{-1}\right), \mathrm{P}_{L B(t o p)}$ is labile $\mathrm{P}$ in the top $1 \mathrm{~cm}$ of the soil $\left(\mathrm{kg}-\mathrm{P}\right.$ ha $\left.{ }^{-1}\right), \Pi_{s r}$ is a transfer function for the dissolved $\mathrm{P}$ transported by surface runoff, $Q_{s r}$ is surface 20 runoff expressed in water depth $(m)$, and $\Omega_{s r}$ is the amount of surface runoff when $63 \%$ of dissolved $\mathrm{P}$ is transported $(\mathrm{m})$. As illustrated in Fig. 6 , the transfer function $\Pi$ in Eq. (37) takes an exponential rise-to-maximum form varying from 0 to 1 according to the ratio of $Q$ to $\Omega$. When $Q$ is equal to $\Omega, 63 \%$ of dissolved $\mathrm{P}$ in the soil is transported. The rationale behind this transfer function is that the amount of dissolved $\mathrm{P}$ transported

HESSD

2, 1359-1404, 2005

\section{A distributed continuous simulation model}

B. K. Koo et al.

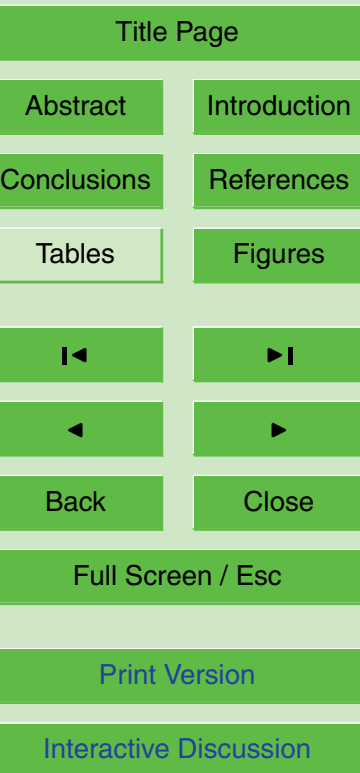

EGU 
by unit water flow decreases as water flow increases. For a given $Q$, a larger $\Omega$ means less transport of dissolved $P$ and vice versa.

Preferential flows through macropores and field drains are an important hydrologic pathway that may transport a significant amount of dissolved P. When water flows 5 through macropores, dissolved $P$ in pore waters adjacent to the flow pathway is transferred to the flowing water by advection and diffusion. Preferential flows are a quick transport system, and the amount of dissolved $P$ that is transported is limited by the interaction between the flowing water and pore waters. In the model, movement of dissolved $\mathrm{P}$ from pore waters to the flowing water takes place at 'interactive zones' which 10 represent interactive pores of the soil around flow pathways. The amount of dissolved $P$ transported by field drain flows is estimated by applying a transfer function to the amount of dissolved $P$ in the interactive zone:

$D P_{f d}=P_{L B(f d)} \cdot \Pi_{f d}$

where $D P_{f d}$ is amount of dissolved $\mathrm{P}$ transported from the soil to the channel by field drain flows $\left(\mathrm{kg}-\mathrm{P}\right.$ ha $\left.{ }^{-1}\right), \mathrm{P}_{L B(f d)}$ is labile $\mathrm{P}$ in the interactive zone between water table and field drains $\left(\mathrm{kg}-\mathrm{P} \mathrm{ha}^{-1}\right), \Pi_{f d}$ is transfer function for dissolved $\mathrm{P}$ transported by field drain flows, similarly defined as in Eq. (37).

Similarly, the amounts of dissolved $\mathrm{P}$ transported through soil macropores to the channel and to the aquifer are estimated by the following:

$D P_{m p}=P_{L B(m p)} \cdot \Pi_{m p}$

$D P_{s a}=P_{L B(s a)} \cdot \Pi_{s a}$

where $D P_{m p}$ is amount of dissolved $\mathrm{P}$ transported from the soil to the channel by macropore flows $\left(\mathrm{kg}-\mathrm{P} \mathrm{ha}^{-1}\right), D P_{s a}$ is amount of dissolved $\mathrm{P}$ transported from the soil to the aquifer by macropore flows $\left(\mathrm{kg}-\mathrm{P} \mathrm{ha}^{-1}\right), \mathrm{P}_{L B(m p)}$ is labile $\mathrm{P}$ in the interactive zone below water table $\left(\mathrm{kg}-\mathrm{P}\right.$ ha $\left.{ }^{-1}\right), \mathrm{P}_{L B(s a)}$ is labile $\mathrm{P}$ in the soil below water table

HESSD

2, 1359-1404, 2005

\section{A distributed continuous simulation model}

B. K. Koo et al.

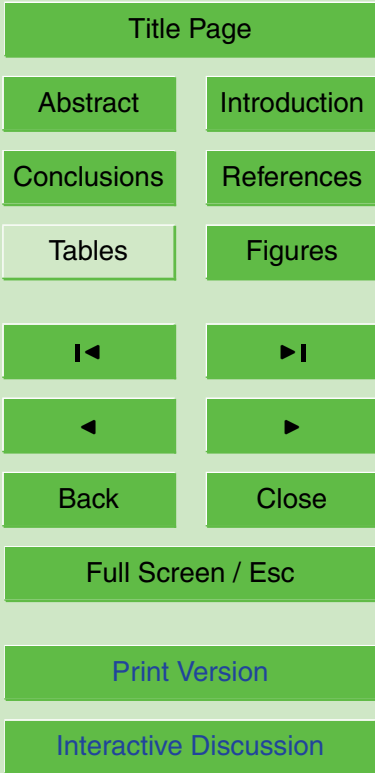

EGU 
(kg-P ha ${ }^{-1}$ ), and $\Pi_{m p}$ and $\Pi_{s a}$ are transfer functions for dissolved $\mathrm{P}$ transported by macropore flow and aquifer recharge flow, respectively.

HESSD

2, 1359-1404, 2005

\subsection{Transformations and transport of dissolved $P$ in the aquifer}

$P$ transformation processes in the aquifer (fast and slow sorption) are estimated using 5 equations similar to Eqs. (27) and (28) based on an assumption that groundwater is completely mixed and that the groundwater temperature is constant. Dissolved $P$ in the aquifer can be transported to the soil by a rise in the groundwater table, to/from the channel by channel-aquifer interaction flows, or to/from the aquifer of neighbouring cells according to water head differences. The amount of dissolved $P$ transported is 10 estimated by multiplying the mean concentration of dissolved $\mathrm{P}$ with the corresponding groundwater flux.

\subsection{Transformations and transport of $P$ in the channel}

Transport of $\mathrm{P}$ along the channel network is calculated using the same approach used for channel routing of sediment particles. $P$ transformation processes (fast and slow 15 sorption) are first estimated for first-order cells and then both particulate and dissolved $\mathrm{P}$ are transported to the downstream channel where $\mathrm{P}$ transformations are estimated taking account of all upstream inputs. Through this comprehensive cascade routing scheme, $\mathrm{P}$ transformations and transport are simulated cell by cell all the way down to the catchment outlet.

20 In-stream $\mathrm{P}$ transformation processes are estimated using equations similar to Eqs. (27) and (28), based on the assumption that the channel water is completely mixed and that the channel water temperature is the same as the soil temperature. The $\mathrm{P}$ adsorption capacity of the channel bed is determined by particle size distributions of the channel bed sediment storage.

25 The amount of particulate $P$ transported by channel flows is estimated for each of the particle size classes by multiplying the amount of sediment transported downstream

\section{A distributed continuous simulation model}

B. K. Koo et al.

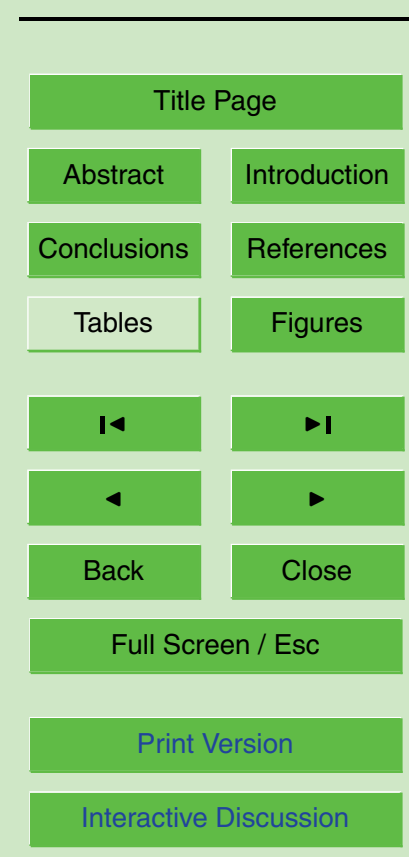

EGU 
with the concentration of particulate $\mathrm{P}$ in the channel bed sediment storage:

$P P_{c h}=S_{c h} \cdot C_{P P(c h)}$

HESSD

where $P P_{c h}$ is amount of particulate $P$ transported by downstream channel flows (kg$\mathrm{P}), S_{c h}$ is sediment transported to downstream by channel flows $(\mathrm{kg})$, and $C_{P P(\mathrm{ch})}$

5 is concentration of particulate $P$ in the channel bed sediment storage $\left(\mathrm{kg}-\mathrm{P} \mathrm{kg}{ }^{-1}\right)$. The value of $C_{P P(c h)}$ is estimated using the composition of the channel bed sediment storage and the $\mathrm{P}$ adsorption capacity of sediment particles.

As complete mixing is assumed in the channel, the amount of dissolved $P$ transported downstream is proportional to the ratio of downstream water discharge to the 10 total amount of interactive water in the channel:

$D P_{c h}=P_{L B(c h)} \frac{Q_{c h}}{Q_{c h}+I W_{c h}}$

where $D P_{c h}$ is amount of dissolved $\mathrm{P}$ transported to the downstream by channel flows $\left(\mathrm{kg}-\mathrm{P} \mathrm{ha}^{-1}\right), \mathrm{P}_{L B(c h)}$ is labile $\mathrm{P}$ in the channel $\left(\mathrm{kg}-\mathrm{P} \mathrm{ha}^{-1}\right), Q_{c h}$ is downstream channel water discharge $\left(\mathrm{m}^{3}\right), I W_{c h}$ is interstitial water in the channel bed which consists of water in the channel bed sediment storage and in the top $1 \mathrm{~cm}$ of the firm channel bed $\left(\mathrm{m}^{3}\right)$. The interstitial water in the top $1 \mathrm{~cm}$ of the firm channel bed is introduced here to prevent all of the dissolved $\mathrm{P}$ from being transported downstream when the channel bed has no loose sediment storage.

\section{Discussion}

\subsection{Suitability of CAMEL for identifying CSAs of $P$}

There are several essential requirements for a catchment model to be able to identify CSAs of $P$ at the catchment scale. Firstly, the catchment model should be spatiallydistributed so that variations of $P$-related processes are simulated across the catchment. CAMEL is fully-distributed in horizontal dimensions, but it is not fully-distributed

\section{A distributed continuous simulation model}

B. K. Koo et al.

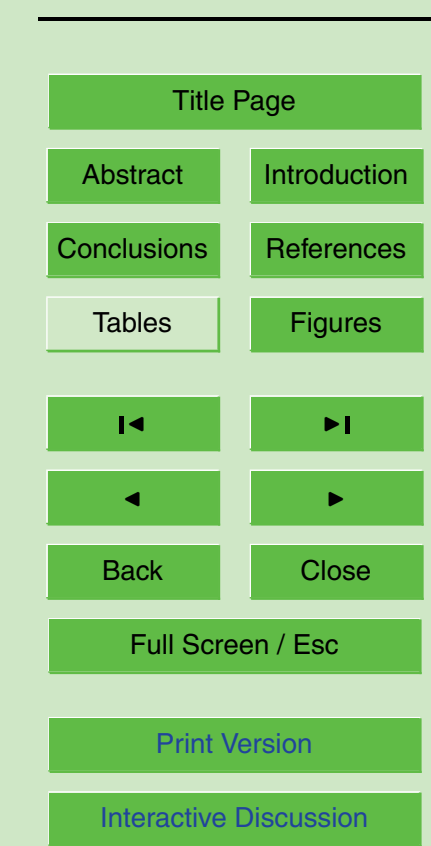

EGU 
vertically, having only one soil layer and two aquifer layers. However, $\mathrm{P}$ transport by surface runoff, which is one of the most significant mechanisms of $P$ transport in many areas, is estimated using $P$ pools in the top $1 \mathrm{~cm}$ of the soil layer. Thus, although the model is not fully-distributed vertically, the $P$ processes are simulated appropriately.

5 Secondly, both surface and subsurface processes should be simulated to take into account the various transport processes of particulate $P$ and dissolved $P$. In CAMEL, surface and subsurface hydrological processes are explicitly represented, as are $P$ transport processes. Particulate $P$ is transported only by surface runoff but dissolved $P$ can be transported by surface runoff, preferential flows, groundwater recharge flux, 10 and groundwater flows.

Thirdly, the fate of $\mathrm{P}$ during transport along a stream channel network should be simulated. CAMEL has a comprehensive cell-by-cell cascade routing scheme for simulating the fate of sediment particles and $P$ along the stream channel network. Thus CAMEL can simulate deposition and re-suspension of particulate $P$, and adsorption 15 and desorption of dissolved $\mathrm{P}$. These together define the $\mathrm{P}$ retention characteristics over time and space.

Thus, CAMEL satisfies the requirements to a reasonable degree and should be appropriate for identifying CSAs of $\mathrm{P}$ at the catchment scale.

\subsection{Other potential application areas}

20 CAMEL can be used for other applications as well as for identifying CSAs. As a distributed process-oriented model, it can be used for estimating land use change impacts on water quality. Land use changes (e.g. afforestation or deforestation) in parts of a catchment can be represented in the model by assigning new land covers to the corresponding grid cells. Changed values of land cover related parameters (e.g. surface roughness, LAl, fertiliser application rate, etc.) in process-oriented equations will be translated into changes in the simulated water flow and water quality. Similarly, CAMEL can also evaluate the effectiveness of certain types of BMPs (best management practices) that may be implemented only in parts of a catchment.

HESSD

2, 1359-1404, 2005

\section{A distributed continuous simulation model}

B. K. Koo et al.

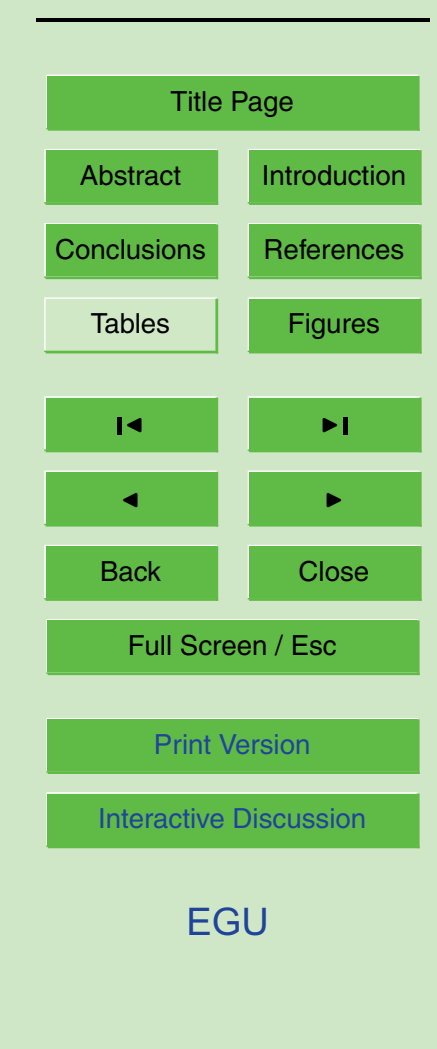


Using a comprehensive cascade channel routing scheme, CAMEL simulates detachment, deposition and re-suspension of sediment particles for four particle-size classes. Although the model cannot take account of in-stream heterogeneity within a grid cell, CAMEL simulates the distribution of sediment particles across the whole stream chan-

5 nel network at every daily time-step. Thus, this capability of the model to simulate sediment distributions over space and time can be useful for certain ecological studies regarding sediment-related stream habitats.

CAMEL also takes into account the effects of soil water content and soil temperature on $\mathrm{P}$ transformation processes. Thus, the model can evaluate, to a degree, potential 0 impacts of climate change on $P$ dynamics in soil and water.

Although it simulates both surface and subsurface processes in a distributed manner, CAMEL sparingly employs iterative numerical approaches. Thus, the computing power required for CAMEL simulations is relatively low, and therefore the model can be used for long-term simulations.

15 7.3. Limitations of CAMEL

CAMEL has some limitations in its representation of hydrological and hydrochemical processes, which stem from the structure of the model. The most significant limitations are considered to be:

- CAMEL has only one soil layer and therefore the state variables such as soil water content need to be aggregated for the whole soil column. This may be reasonable for shallow soils, but may not be so for deep soils.

- As the model runs at daily time-steps, state variables are estimated using daily mean values. For estimating slow/steady-processes (e.g. aquifer recharge), daily mean values are reasonable. But for fast/ephemeral-processes (e.g. infiltrationexcess runoff), daily mean values may not be appropriate and this could be a major limitation. For example, CAMEL estimates the accumulated infiltration using an hourly rainfall intensity derived from the daily mean. This is likely to sub-

\section{A distributed continuous simulation model}

B. K. Koo et al.

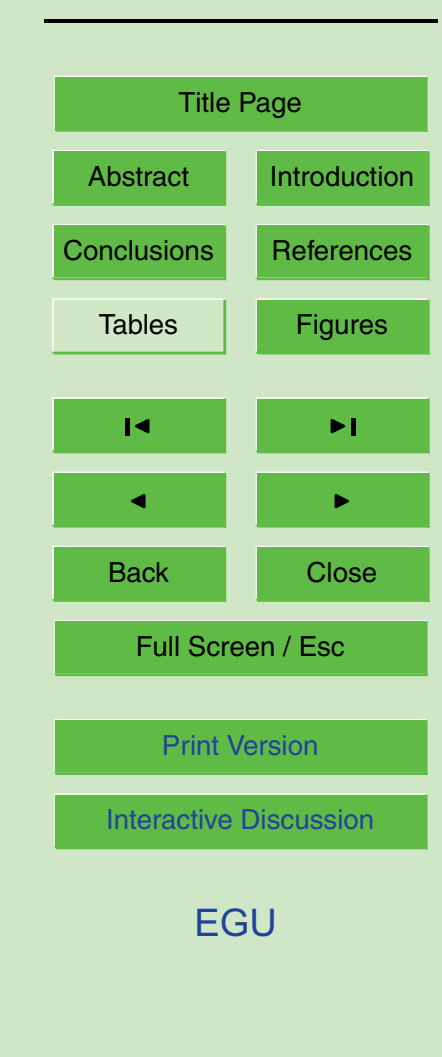


stantially underestimate the real hourly rainfall intensity during storm events. This means that the model is likely to overestimate the accumulated infiltration and consequently underestimate infiltration excess and sediment transport capacity of the surface runoff. This limitation of the model could be alleviated by using rainfall duration data to estimate hourly rainfall intensities. However, this is not included in the current version of the model.

- The current version of the model has no snow component and cannot simulate snow melting events.

- The channel routing components of the model does not allow for lakes or reservoirs.

- In the model, inorganic $P$ is transported in either particulate or dissolved forms, but no transport of organic $P$ is taken into consideration. This is reasonable for intensive agricultural areas where a large amount of inorganic $P$ fertilisers are applied on a regular basis. However, it may not be appropriate for non-agricultural areas or intensive livestock farming areas where the transport of organic $P$ is significant.

- CAMEL has no biological components for in-stream P dynamics and thus cannot simulate decomposition and mineralisation of organic materials or uptake of $\mathrm{P}$ by phytoplankton and algae;

20 The authors hope that these limitations of CAMEL will be addressed in future versions of the model.

\section{Conclusions}

Phosphorus $(\mathrm{P})$ transformation and transport processes vary greatly in time and space. For effective implementation of $P$ control measures in a catchment, it is of utmost im-

HESSD

$2,1359-1404,2005$

\section{A distributed continuous simulation model}

B. K. Koo et al.

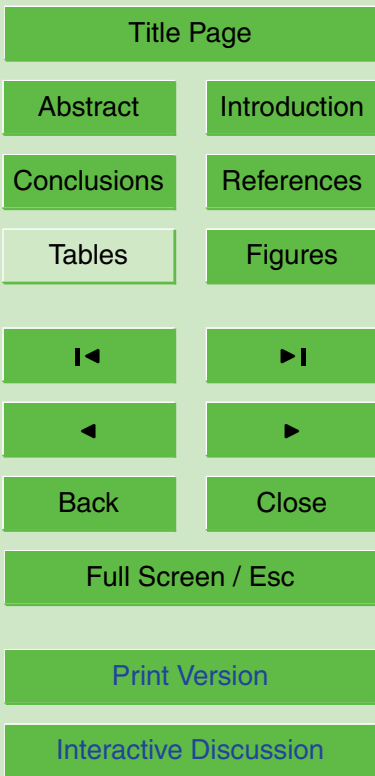

EGU 
from CSAs. A mathematical model can be a useful tool for identifying CSAs of $P$ if the model structure is appropriate.

A distributed continuous simulation model, CAMEL (Chemicals from Agricultural Management and Erosion Losses), has been developed for simulating daily transport

5 of water, sediment and $P$ at the catchment scale. CAMEL describes a catchment using a network of square grid cells that represent corresponding soil-aquifer columns. Every grid cell consists of various storages of water (canopy, soil, aquifer and channel water), sediment (overland and channel-bed sediment) and $\mathrm{P}$ (active organic, stable organic, labile, active inorganic and stable inorganic P), and hydrological and hydro10 chemical processes are described as movements of mass between these storages. With a network of self-contained cells and comprehensive routing schemes, CAMEL is able to simulate both surface and subsurface processes. Although a few conceptual approaches are used, most of the hydrological and hydrochemical processes in the model are represented using process-based equations.

The distributed, process-oriented structure of CAMEL enables the model to be used for identifying CSAs of $P$ at the catchment scale. With sparingly employed iterative numerical approaches, CAMEL requires a relatively low cost of computing power, which allows for long-term scale applications such as evaluating climate change impacts on water quality. The model has been designed to suit the Scottish environment, but is appropriate for application elsewhere in the temperate region.

\section{Notation}

$\alpha, \beta$ experimentally-determined coefficients to estimate sediment transport capacity (dimensionless)

$\gamma \quad$ psychrometric constant $\left(\mathrm{kPa}{ }^{\circ} \mathrm{C}^{-1}\right)$

$\delta \quad$ gradient of saturated vapour pressure over temperature $\left(\mathrm{kPa}^{\circ} \mathrm{C}^{-1}\right)$

\section{A distributed continuous simulation model}

B. K. Koo et al.

$\delta_{b} \quad$ bulk density of the soil $\left(\mathrm{g} \mathrm{cm}^{-3}\right)$

$\varepsilon_{d} \quad$ detachment efficiency coefficient (dimensionless)

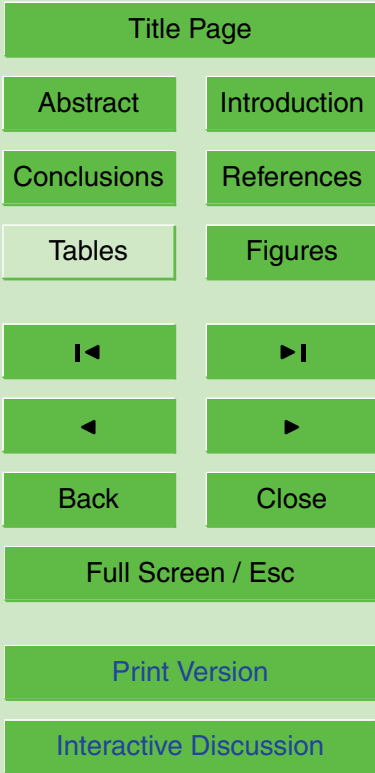


$\varepsilon_{P} \quad$ enrichment ratio of $\mathrm{P}$ (dimensionless)

HESSD

$\zeta$ cohesion of wet soil $(\mathrm{kPa})$

$\eta \quad$ soil detachability index $\left(\mathrm{g} \mathrm{J}^{-1}\right)$

2, 1359-1404, 2005

$\theta \quad$ soil water content $\left(\mathrm{m}^{3} \mathrm{~m}^{-3}\right)$

$\theta_{\text {res }}$ residual soil water content $\left(\mathrm{m}^{3} \mathrm{~m}^{-3}\right)$

$\theta_{\text {sat }}$ saturated soil water content $\left(\mathrm{m}^{3} \mathrm{~m}^{-3}\right)$

$l \quad$ rainfall intensity $\left(\mathrm{mm} \mathrm{h}^{-1}\right)$

$\kappa$ thermal diffusivity of the soil $\left(\mathrm{cm}^{2} \mathrm{~s}^{-1}\right)$

$\lambda \quad$ latent heat of vaporisation of water $\left(\mathrm{MJ} \mathrm{kg}^{-1}\right)$

$\lambda_{c} \quad$ fraction of ground surface covered by plant canopy (dimensionless)

$\mu \quad$ ratio of potential crop coefficient for a given day to the maximum crop coefficient $\left(=K_{c o} / K_{c o(\max )}\right)$

$v \quad$ settling velocity of sediment particles $\left(\mathrm{m} \mathrm{s}^{-1}\right)$

$\xi_{d} \quad$ active organic $\mathrm{P}$ decomposition rate $\left(\mathrm{kg}-\mathrm{P}\right.$ ha ${ }^{-1}$ day $\left.^{-1}\right)$

$\xi_{m} \quad \mathrm{P}$ mineralisation rate $\left(\mathrm{kg}-\mathrm{P}\right.$ ha $\left.{ }^{-1} \mathrm{day}^{-1}\right)$

$\xi_{r a} \quad$ rapid adsorption rate of $\mathrm{P}$ from $P_{L B}$ to $P_{A I}\left(\mathrm{~kg}-\mathrm{P}\right.$ ha ${ }^{-1}$ day $\left.^{-1}\right)$

$\xi_{s a} \quad$ slow adsorption rate of $\mathrm{P}$ from $P_{A l}$ to $P_{S I}\left(\mathrm{~kg}-\mathrm{P}\right.$ ha ${ }^{-1}$ day $\left.{ }^{-1}\right)$

$\rho \quad$ density of sediment particles $\left(=2650 \mathrm{~kg} \mathrm{~m}^{-3}\right)$

$\sigma_{r a}$ equilibrium coefficient for rapid adsorption (dimensionless)

$\checkmark \quad$ fraction of a given particle size class in the top soil (dimensionless)

$\phi \quad$ median particle size $(\mu \mathrm{m})$

$\omega \quad$ unit stream power $\left(\mathrm{cm} \mathrm{s}^{-1}\right)$

$\varpi \quad$ critical value of unit stream power $\left(\mathrm{cm} \mathrm{s}^{-1}\right)$

$\Delta / \quad$ field drain spacing $(\mathrm{m})$

$\Delta t \quad$ time step (day)

$\Delta x \quad$ cell size $(\mathrm{m})$

$\Pi_{f d} \quad$ transfer function for dissolved $\mathrm{P}$ transported by field drain flow (dimensioless)

\section{A distributed continuous simulation model}

B. K. Koo et al.

\section{Title Page}

Abstract

Conclusions

Tables

\section{4}

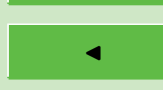

Back

Full Screen / Esc

Print Version

Interactive Discussion 


\begin{tabular}{|c|c|}
\hline $1_{m p}$ & $\begin{array}{l}\text { ansfer function for dissolved } \mathrm{P} \text { transported by macropore flow (dimen- } \\
\text { onless) }\end{array}$ \\
\hline sa & $\begin{array}{l}\text { unction for dissolved } \mathrm{P} \text { transported by aquifer recharge flow } \\
\text { onless) }\end{array}$ \\
\hline$s r$ & function for dissolved P transported by surface runoff (dimen- \\
\hline$-s r$ & f surface runoff when $63 \%$ of dissolved $\mathrm{P}$ is transported $(\mathrm{m})$ \\
\hline$A_{h}$ & gy advected to the water body ( $\mathrm{MJ} \mathrm{m}^{-2}$ day $\left.^{-1}\right)$ \\
\hline 6 & nensionless) \\
\hline$C$ & ation in the rill flow $\left(\mathrm{kg} \mathrm{m}^{-3}\right)$ \\
\hline$C \%$ & 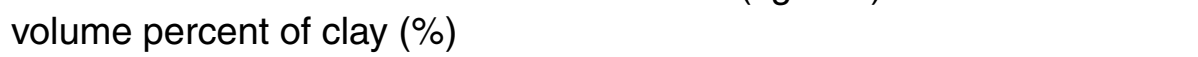 \\
\hline$C_{D P(r z)}$ & oncentration of dissolved $\mathrm{P}$ in the root zone $\left(\mathrm{kg}-\mathrm{P} \mathrm{m} \mathrm{m}^{-3}\right)$ \\
\hline$C_{P P(c h)}$ & $\begin{array}{l}\text { oncentration of particulate } \mathrm{P} \text { in the channel bed sediment storage }(\mathrm{kg}- \\
\left.\mathrm{kg}^{-1}\right)\end{array}$ \\
\hline$C_{P P(t o}$ & concentration of particulate $P$ in the top $1 \mathrm{~cm}$ of the soil $\left(\mathrm{kg}-\mathrm{P} \mathrm{kg}^{-1}\right)$ \\
\hline$d_{e q}$ & alent depth in Hooghoudt equation (m) \\
\hline$d_{\text {soil }}$ & of the soil layer $(\mathrm{m})$ \\
\hline$d_{s w}$ & f overland surface water (mm) \\
\hline$D$ & pressure deficit $(\mathrm{kPa})$ \\
\hline$D P_{c h}$ & $\begin{array}{l}\text { unt of dissolved } \mathrm{P} \text { transported to the downstream by channel flows } \\
\mathrm{ha}^{-1} \text { ) }\end{array}$ \\
\hline$D P_{f d}$ & $\begin{array}{l}\text { unt of dissolved } P \text { transported from the soil to the channel by field } \\
\text { flows }\left(\mathrm{kg}-\mathrm{P} \mathrm{ha}^{-1}\right)\end{array}$ \\
\hline$D P_{m p}$ & $\begin{array}{l}\text { unt of dissolved } \mathrm{P} \text { transported from the soil to the channel by } \\
\text { ropore flows }\left(\mathrm{kg}-\mathrm{P} \mathrm{ha} \mathrm{ha}^{-1}\right)\end{array}$ \\
\hline$D P_{s}$ & $\begin{array}{l}\text { unt of dissolved } \mathrm{P} \text { transported from the soil to the aquifer by macro- } \\
\text { flows }\left(\mathrm{kg}-\mathrm{P} \mathrm{ha} \mathrm{ha}^{-1}\right)\end{array}$ \\
\hline
\end{tabular}

\section{A distributed continuous simulation model}
B. K. Koo et al.

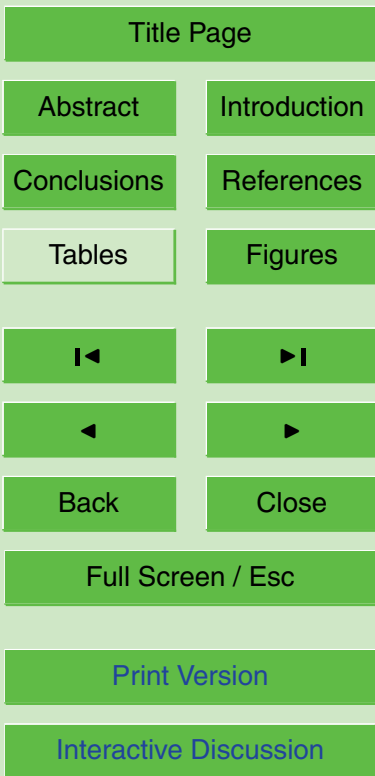

EGU 
$D P_{s r}$ amount of dissolved $\mathrm{P}$ transported from the top soil to the channel by surface runoff $\left(\mathrm{kg}-\mathrm{P} \mathrm{ha}^{-1}\right)$

$E_{c} \quad$ transpiration rate of a crop $\left(\mathrm{mm} \mathrm{day}^{-1}\right)$

HESSD

$E_{p} \quad$ potential evaporation rate $\left(\mathrm{mm} \mathrm{day}^{-1}\right)$

$E_{r c} \quad$ reference crop transpiration rate $\left(\mathrm{mm}\right.$ day $\left.^{-1}\right)$

$E_{s} \quad$ evaporation rate from the soil surface $\left(\mathrm{mm} \mathrm{day}^{-1}\right)$

$f \quad$ infiltration rate $\left(\mathrm{mm} \mathrm{hr}^{-1}\right)$

$F \quad$ accumulated infiltration (mm)

$F D \quad$ sediment detachment by rill flow $\left(\mathrm{kg} \mathrm{m}^{-1} \mathrm{~s}^{-1}\right)$

$G \quad$ heat conduction into the soil $\left(\mathrm{MJ} \mathrm{m}^{-2}\right.$ day $\left.^{-1}\right)$

$h \quad$ elevation of groundwater table $(\mathrm{m})$

$H$ saturated thickness of the aquifer $(\mathrm{m})$

$H_{c} \quad$ canopy height $(\mathrm{m})$

$I_{C} \quad$ canopy interception $(\mathrm{mm})$

$I W_{c h}$ interstitial water in the channel bed which consists of water in the channel bed sediment storage and in the top $1 \mathrm{~cm}$ of the firm channel bed $\left(\mathrm{m}^{3}\right)$

$k_{\theta} \quad$ soil water adjustment factor (dimensionless)

$k_{d} \quad$ rate coefficient for active organic matter decomposition (day ${ }^{-1}$ )

$k_{e} \quad$ extinction coefficient for solar radiation interception through the canopy

$k_{\text {eff }} \quad$ effective hydraulic conductivity of the soil $\left(\mathrm{m} \mathrm{h}^{-1}\right.$ or $\mathrm{m} \mathrm{day}^{-1}$ )

$k_{h} \quad$ rate coefficient for humus mineralisation $\left(\right.$ day $^{-1}$ )

$k_{r a} \quad$ rate coefficient for rapid adsorption of $\mathrm{P}$ from $P_{L B}$ to $P_{A l}\left(\right.$ day $\left.^{-1}\right)$

$k_{s a} \quad$ rate coefficient for slow adsorption of $\mathrm{P}$ from $P_{A /}$ to $P_{S I}\left(\right.$ day $\left.^{-1}\right)$

$k_{\text {sat }} \quad$ saturated hydraulic conductivity of the soil $\left(\mathrm{m} \mathrm{day}^{-1}\right)$

$k_{T B} \quad$ temperature adjustment factor for biochemical processes (dimensionless)

$k_{T S} \quad$ temperature adjustment factor for sorption (dimensionless)

\section{A distributed continuous simulation model}

B. K. Koo et al.

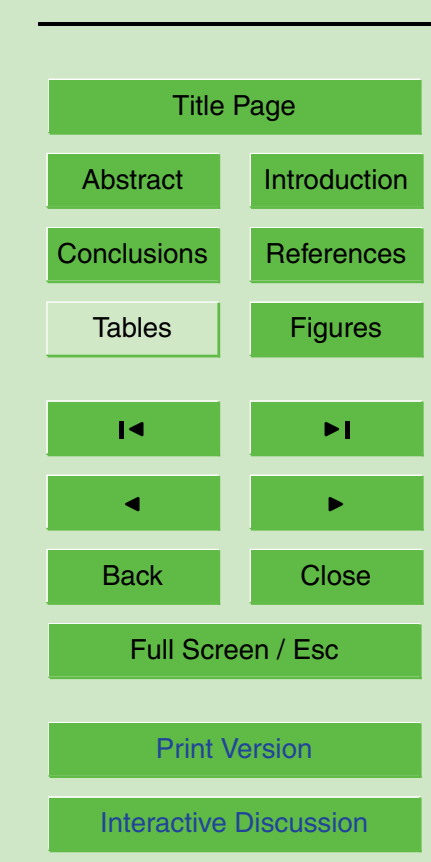

EGU 
$k_{\text {unsat }} \quad$ unsaturated hydraulic conductivity of the soil $\left(\mathrm{m} \mathrm{day}^{-1}\right)$

HESSD

$k_{\psi} \quad$ soil water stress factor (dimensionless)

$K_{c o} \quad$ potential crop coefficient (dimensionless)

$K E_{\text {I }} \quad$ kinetic energy of leaf drainage from the canopy $\left(\mathrm{J} \mathrm{m}^{-2}\right)$

$K E_{r} \quad$ kinetic energy of direct rainfall $\left(\mathrm{J} \mathrm{m}^{-2}\right)$

$K_{\text {sat }} \quad$ saturated hydraulic conductivity of the fast-flowing aquifer layer ( $\mathrm{m}$ day $^{-1}$ )

$L A I \quad$ leaf area index $\left(\mathrm{m}^{2} \mathrm{~m}^{-2}\right)$

LIT LAI equivalent of ground litter $\left(\mathrm{m}^{2} \mathrm{~m}^{-2}\right)$

$L L \quad$ combined index of leaf area and ground litter $\left(\mathrm{m}^{2} \mathrm{~m}^{-2}\right)$

$m$ soil evaporation coefficient (dimensionless)

$M \quad$ Michaelis-Menten's half-saturation constant of dissolved $\mathrm{P}$ concentration for a given plant $\left(\mathrm{kg}-\mathrm{P} \mathrm{m}^{-3}\right)$

$n \quad$ Averjanov's exponent (dimensionless)

$p \quad$ period of diurnal temperature variation (=86400 s)

$P_{A l} \quad$ active inorganic $\mathrm{P}$ storage $\left(\mathrm{kg}-\mathrm{P}\right.$ ha $\left.{ }^{-1}\right)$

2, 1359-1404, 2005

$P_{A O} \quad$ active organic $\mathrm{P}$ in the soil $\left(\mathrm{kg}-\mathrm{P} \mathrm{ha}^{-1}\right)$

$P_{L B} \quad$ labile $\mathrm{P}$ storage $\left(\mathrm{kg}-\mathrm{P} \mathrm{ha}^{-1}\right)$

$P_{L B(c h)} \quad$ labile $\mathrm{P}$ in the channel $\left(\mathrm{kg}^{-\mathrm{P}} \mathrm{ha}^{-1}\right)$

$P_{L B(f d)} \quad$ labile $\mathrm{P}$ in the interactive zone between water table and field drains $(\mathrm{kg}$ $P$ ha $^{-1}$ )

$P_{L B(m p)} \quad$ labile $\mathrm{P}$ in the interactive zone below water table $\left(\mathrm{kg} \mathrm{P}\right.$ ha $\left.{ }^{-1}\right)$

A distributed continuous simulation model

B. K. Koo et al.

$P_{L B(s a)} \quad$ labile $\mathrm{P}$ in the soil below water table $\left(\mathrm{kg}-\mathrm{P} \mathrm{ha}^{-1}\right)$

$P_{L B(t o p)} \quad$ labile $\mathrm{P}$ in the top $1 \mathrm{~cm}$ of the soil $\left(\mathrm{kg}^{\mathrm{P}} \mathrm{P}\right.$ ha $\left.{ }^{-1}\right)$

$P P_{c h} \quad$ amount of particulate $P$ transported by downstream channel flows $(\mathrm{kg}$ P)

$P P_{s r} \quad$ amount of particulate $\mathrm{P}$ transported from the soil to the channel $(\mathrm{kg}-\mathrm{P}$ $\mathrm{ha}^{-1}$ )

Title Page

Abstract

Introduction

Conclusions

References

Tables

Figures

14

4

Back

Close

Full Screen / Esc

Print Version

Interactive Discussion 
$P_{S I} \quad$ stable inorganic $\mathrm{P}$ in the soil $\left(\mathrm{kg}-\mathrm{P} \mathrm{ha}^{-1}\right)$

HESSD

$P_{S O} \quad$ stable organic $\mathrm{P}$ in the soil $\left(\mathrm{kg}-\mathrm{P} \mathrm{ha}^{-1}\right)$

2, 1359-1404, 2005

$P_{u p} \quad \mathrm{P}$ uptake rate by a given plant $\left(\mathrm{kg}-\mathrm{P} \mathrm{ha}^{-1} \mathrm{day}^{-1}\right)$

$q_{r} \quad$ flow rate in a rill $\left(\mathrm{m}^{3} \mathrm{~s}^{-1}\right)$

$q_{\text {sa }}$ amount of water flow from the soil to the aquifer, calculated for individual $0.1 \%$ soil water content $\left(\mathrm{m}^{3}\right)$

$Q_{c h} \quad$ downstream channel water discharge $\left(\mathrm{m}^{3}\right)$

$Q_{f d} \quad$ preferential flow through field drains $\left(\mathrm{m}^{3}\right.$ day $\left.^{-1}\right)$

$Q_{s a} \quad$ total water flow from the soil to the aquifer $\left(\mathrm{m}^{3}\right.$ day $\left.^{-1}\right)$

$Q_{s r} \quad$ surface runoff expressed in water depth (m)

$R \quad$ daily rainfall $(\mathrm{mm})$

$R_{n} \quad$ net radiation exchange for the free water surface (MJ m ${ }^{-2}$ day $^{-1}$ )

$s \quad$ energy slope of water (dimensionless)

$S \quad$ storage coefficient of the aquifer $\left(\mathrm{m} \mathrm{m}^{-1}\right)$

S\% volume percent of sand (\%)

$S_{c h} \quad$ sediment transported to downstream by channel flows $(\mathrm{kg})$

$S D$ splash detachment by rain drop impact $\left(\mathrm{kg} \mathrm{ha}^{-1}\right)$

$S_{f} \quad$ matric potential of suction at the wetting front $(\mathrm{mm})$

$S_{s r} \quad$ sediment transported to the channel by surface runoff $\left(\mathrm{kg} \mathrm{ha}^{-1}\right)$

$t \quad$ time (day)

$t_{T} \quad$ travel time of the recharge flow (day)

$T$ daily mean air temperature $\left({ }^{\circ} \mathrm{C}\right)$

$T^{\prime} \quad$ daily mean soil temperature $\left({ }^{\circ} \mathrm{C}\right)$

TC sediment transport capacity of the rill flow $\left(\mathrm{kg} \mathrm{m}^{-3}\right)$

$\bar{u} \quad$ mean flow velocity $\left(\mathrm{cm} \mathrm{s}^{-1}\right)$

$U_{2} \quad$ wind speed measured at $2 \mathrm{~m}$ above the ground surface $\left(\mathrm{m} \mathrm{s}^{-1}\right)$

$U_{\max }$ maximum rate of $\mathrm{P}$ uptake by a given plant $\left(\mathrm{kg}-\mathrm{P} \mathrm{ha}^{-1} \mathrm{day}^{-1}\right)$

\section{A distributed continuous simulation model}

B. K. Koo et al.

\section{Title Page}

Abstract

Introduction

Conclusions

References

Tables

Figures

14

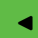

Back
Full Screen / Esc

Print Version

Interactive Discussion 
$v \quad$ settling vecolity of sediment particles $\left(\mathrm{m} \mathrm{s}^{-1}\right)$

HESSD

$V_{s s}$ volume of the soil layer $\left(\mathrm{m}^{3}\right)$

$W_{r} \quad$ width of rill flows $(\mathrm{m})$

$z \quad$ soil depth $(\mathrm{m})$

Acknowledgements. This study has been funded by the Scottish Executive Environment and Rural Affairs Department, which is gratefully acknowledged by the authors.

\section{References}

5 Arnold, J. G., Williams, J. R., Griggs, R. H., and Sammons, N. B.: SWRRBWQ - A Basin Model for Assessing Management Impacts on Water Quality (Draft), USDA ARS, Grassland, Soil, and Water Research Laboratory, Temple, TX, 1991.

Averjanov, S. F.: About permeability of subsurface soils in case of incomplete saturation, English Collection, 7, 19-21, 1950 (as quoted by Palubarinova, P. Ya.: The theory of ground water movement (English translation by DeWiest, I. M. R.), Princeton University Press, Princeton, NJ, 1962).

Barber, S. A.: Soil-plant interactions in the phosphorus nutrition of plants, in: The Role of Phosphorus in Agriculture, edited by: Khasawneh, F. E., Sample, E. C., and Kamprath, E. J., Am. Soc. Agronomy, Crop Sci. Soc. Am., Soil Sci. Soc. Am., Madison, Wisconsin, US, 15 591-615, 1980.

Bicknell, B. R., Imhoff, J. C., Kittle, J. L., Jr., Donigian, A. S., Jr., and Johanson, R. C.: Hydrological Simulation Program - Fortran: User's manual for version 11, U.S. Environmental Protection Agency, National Exposure Research Laboratory, Athens, GA, EPA/600/R-97/080, 755 pp., 1997.

20 Bouraoui, F. and Dillaha, T. A.: ANSWERS-2000 - Nonpoint Source Nutrient Transport Model, J. Environ. Eng., 126, 1045-1055, 2000.

Bowes, M. J., House, W. A., and Hodgkinson, R. A.: Phosphorus dynamics along a river continuum, Sci. Total Environ. 313, 199-212, 2003.

Brakensiek, D. L. and Rawls, W. J.: Effects of agricultural and rangeland management systems on infiltration, in: Modeling Agricultural, Forest and Rangeland Hydrology, ASAE, St. Joseph, Mich., 247, 1988.

\section{A distributed continuous simulation model}

B. K. Koo et al.

\section{Title Page}

\section{Abstract} Introduction

Conclusions References

Tables Figures

14

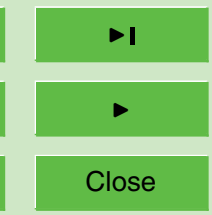

Back

Full Screen / Esc

Print Version

Interactive Discussion

EGU 
Brandt, C. J.: The size distribution of throughfall drops under vegetation canopies, Catena 16, 507-524, 1989.

Brandt, C. J.: Simulation of the size distribution and erosivity of raindrops and throughfall drops, Earth Surface Processes and Landforms 15, 687-698, 1990.

5 Campbell, K. L., Kiker, G. A., and Clark, D. J.: Development and testing of a nitrogen and phosphorus process model for Southern African water quality issues, ASAE Annual International Meeting, 30 July-1 August 2001, Sacramento, CA, USA, paper no. 01-2085, 17, 2001.

Chapman, A. S., Foster, I. D. L., Lees, J. A., Hodgkinson, R. A., and Jackson, R. H.: Particulate phosphorus transport by sub-surface drainage from agricultural land in the UK - Environmental significance at the catchment and national scale, Sci. Total Environ., 266, 95-102, 2001.

Cronshey, R. G. and Theurer, F. D.: AnnAGNPS - Non-point pollutant loading model, Proceedings of the 1st Federal Interagency Hydrologic Modeling Conference, Las Vegas, Nevada, 19-23 April 1998, 1-9 to 1-16, 1998.

15 Dils, R. M. and Heathwaite, A. L.: The controversial role of tile drainage in phosphorus export from agricultural land, Water Sci. Tech., 39, 55-61, 1999.

Gardner, C. M. K., Cooper, D. M., and Hughes, S.: Phosphorus in soils and field drainage water in the Thame catchment, UK, Sci. Total Environ., 282/283, 253-262, 2002.

Gburek, W. J. and Sharpley, A. N.: Hydrologic controls on phosphorus loss from upland agricultural watersheds, J. Env'tal. Qual., 27, 267-277, 1998.

Gilley, J. E., Kottwitz, E. R., and Simanton, J. R.: Hydraulic characteristics of rills, Trans. ASAE, 33, 1900-1906, 1990.

Govers, G.: Empirical relationships on the transport capacity of overland flow, Proceedings of the Jerusalem Workshop, Erosion, Transport and Deposition Processes, March-April 1987, IAHS Publ. No. 189, 45-63, 1990.

Green, W. H. and Ampt, G. A.: Studies on soil physics, 1. The flow of air and water through soils, J. Agric. Sci., 4, 11-24, 1911.

Gupta, A., Destouni, G., and Jensen, M. B.: Modelling tritium and phosphorus transport by preferential flow in structured soil, J. Contam. Hydrol., 35, 389-407, 1999.

30 Haygarth, P. M. and Jarvis, S. C.: Soil derived phosphorus in surface runoff from grazed grassland lysimeters, Water Res., 11, 140-148, 1997.

Heathwaite, A. L. and Dils, R. M.: Characterising phosphorus loss in surface and subsurface hydrological pathways, Sci. Total Env., 251/252, 523-538, 2000.

HESSD

$2,1359-1404,2005$

\section{A distributed continuous simulation model}

B. K. Koo et al.

\section{Title Page}

Abstract Introduction

Conclusions References

Tables Figures

14

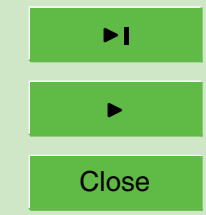

Back

Full Screen / Esc

Print Version

Interactive Discussion

EGU 
Heathwaite, A. L., Haygarth, P. M., and Dils, R.M.: Pathways of phosphorus transport, in: Agricultural Phosphorus in the Chesapeake Bay Watershed - Current Status and Future Trends, edited by: Sharpley, A. N., USDA-ARS Chesapeake Bay Consortium, 2000.

Hooghoudt, S. B.: Bijdrage tot de kennis van enige natuurkundige grootheden van de grond, Verslagen van Landbouwkundiege Onderzoekingen, 46, 515-707, 1940.

House, W. A., Denison, F. A., and Armitage, P. D.: Comparison of the uptake of inorganic phosphorus to a suspended and stream bed-sediment, Water Res., 29, 767-779, 1995.

Jones, C. A., Cole C. V., Sharpley A. N., and Williams, J. R.: A simplified soil and plant phosphorus model, I. Documentation, Soil Sci. Soc. Am. J. 48, 800-805, 1984.

10 Kang, S, Kim, S., Oh, S., and Lee, D.: Predicting spatial and temporal patterns of soil temperature based on topography, surface cover and air temperature, Forest Ecol. Manage. 136, 173-184, 2000.

Lilly, A., Hudson, G., Birnie, R. V., and Horne, P. L.: The inherent geomorphological risk of soil erosion by overland flow in Scotland, Scottish Natural Heritage Research, Survey and

15 Monitoring Report No. 183, 2002.

Lloyd, J. and Taylor, J. A.: On the temperature dependence of soil respiration, Functional Ecology 8, 315-323, 1994.

Maidment, D. R.: Developing a spatially distributed unit hydrograph by using GIS, HydroGIS 93: Application of GIS in Hydrology and Water Resources, IAHS Publ. No. 211, 181-192, 1993.

McGechan, M. B.: Effects of timing of slurry spreading on leaching of soluble and particulate inorganic phosphorus explored using the MACRO model, Biosyst. Eng., 83, 237-252, 2002.

McGechan, M. B., Jarvis, N. J., Hooda, P. S., and Vinten, A. J. A.: Parameterization of the MACRO model to represent leaching of colloidally attached inorganic phosphorus following slurry spreading, Soil Use Manage, 18, 61-67, 2002.

Mein, R. G. and Larson, C. L.: Modeling infiltration during a steady rain, Water Resour. Res., 9, 384-394, 1973.

Menzel, R. G.: Enrichment ratios for water quality modeling, in: CREAMS - A field scale model for chemicals, runoff, and erosion from agricultural management systems, edited by: Knisel,

$30 \quad$ W. G., USDA Conserv. Res. Rept. No. 26, 486-492, 1980.

Morgan, R. P. C., Quinton, J. N., Smith, R. E., Govers, G., Poesen, J. W. A., Auerswald, K., Chisci, G., Torri, D., Styczen, M. E., and Folly, A. J. V.: The European Soil Erosion Model (EUROSEM) - Documentation and user guide, Cranfield University, UK, 1998.

HESSD

$2,1359-1404,2005$

\section{A distributed continuous simulation model}

B. K. Koo et al.

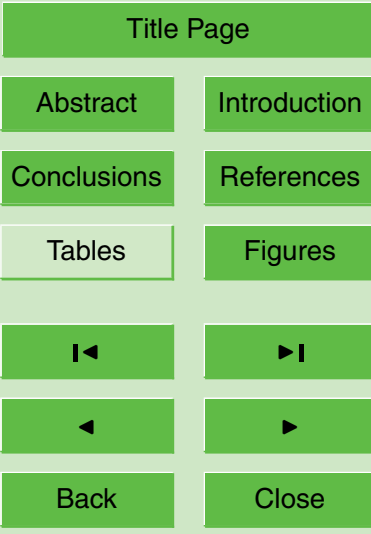

Full Screen / Esc

Print Version

Interactive Discussion

EGU 
Needelman, B. A., Gburek, W. J., Sharpley, A. N., and Petersen, G. W.: Environmental management of soil phosphorus: Modeling spatial variability in small fields, Soil Sci. Soc. Am. J. 65, 1516-1522, 2001.

Neitsch, S. L., Arnold, J. G., Kiniry, J. R., and Williams, J. R.: Soil and water assessment tool

5 - Theoretical documentation, Grassland, Soil and Water Research Laboratory, Agricultural Research Service, http://www.brc.tamus.edu/swat, 2001.

Rauws, G. and Govers, G.: Hydraulic and soil mechanical aspects of rill generation on agricultural soils, J. of Soil Sci., 39, 111-124, 1988.

Rawls, W. J., Brakensiek, D. L., and Savabi, R.: Infiltration parameters for rangeland soils, J. Range Manage, 42, 139-142, 1989.

Shuttleworth, W. J.: Evaporation, in: Handbook of Hydrology, edited by: Maidment, D., McGraw-Hill, 4.1-4.53, 1993.

Simard, R. R., Beauchemin, S., and Haygarth, P. M.: Potential for preferential pathways of phosphorus transport, J. Environ. Qual., 29, 97-105, 2000.

Smith, R, Goodrich, D., and Quinton, J.: Dynamic, distributed simulation of watershed erosion: The KINEROS2 and EUROSEM models, J. Soil Water Conserv., 50, 517-520, 1995.

Theurer, F. D. and Cronshey, R. G.: AnnAGNPS - Reach routing processes, Proceedings of the First Federal Interagency Hydrologic Modeling Conference, Las Vegas, Nevada, 19-23 April 1998, 1-25-1-32, 1998.

20 Viney, N. R., Sivapalan, M., and Deeley, D.: A conceptual model of nutrient mobilisation and transport applicable at large catchment scales, J. Hydrol., 240, 23-44, 2000.

Wade, A. J., Whitehead, P. G., and Butterfield, D.: The integrated catchments model of phosphorus dynamics (INCA-P), a new approach for multiple source assessment in heterogeneous river systems: model structure and equations, Hydrol. Earth Sys. Sci., 6, 583-606, 2002, SRef-ID: 1607-7938/hess/2002-6-583.

Walling, D. E., Webb, B. W., and Russell, M. A.: Sediment-associated nutrient transport in UK rivers. in: Freshwater contamination, Proc. Rabat Symp., April-May 1997, Int. Assoc. Hydrol. Sci.; IAHS Publ. No. 243, 69-81, 1997.

Williams, J. R.: Sediment-yield prediction with universal equation using runoff energy factor, in: Present and Prospective Technology for Predicting Sediment Yield and Sources, ARS, S-40 US Gov. Print Office, Washington, D.C., 244-252, 1975.

HESSD

2, 1359-1404, 2005

\section{A distributed continuous simulation model}

B. K. Koo et al.

\section{Title Page}

\section{Abstract}

Introduction

Conclusions

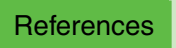

Tables

Figures

14

$\triangleleft$

Back

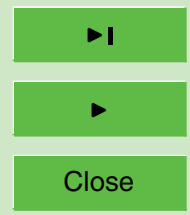

Full Screen / Esc

Print Version

Interactive Discussion

EGU 


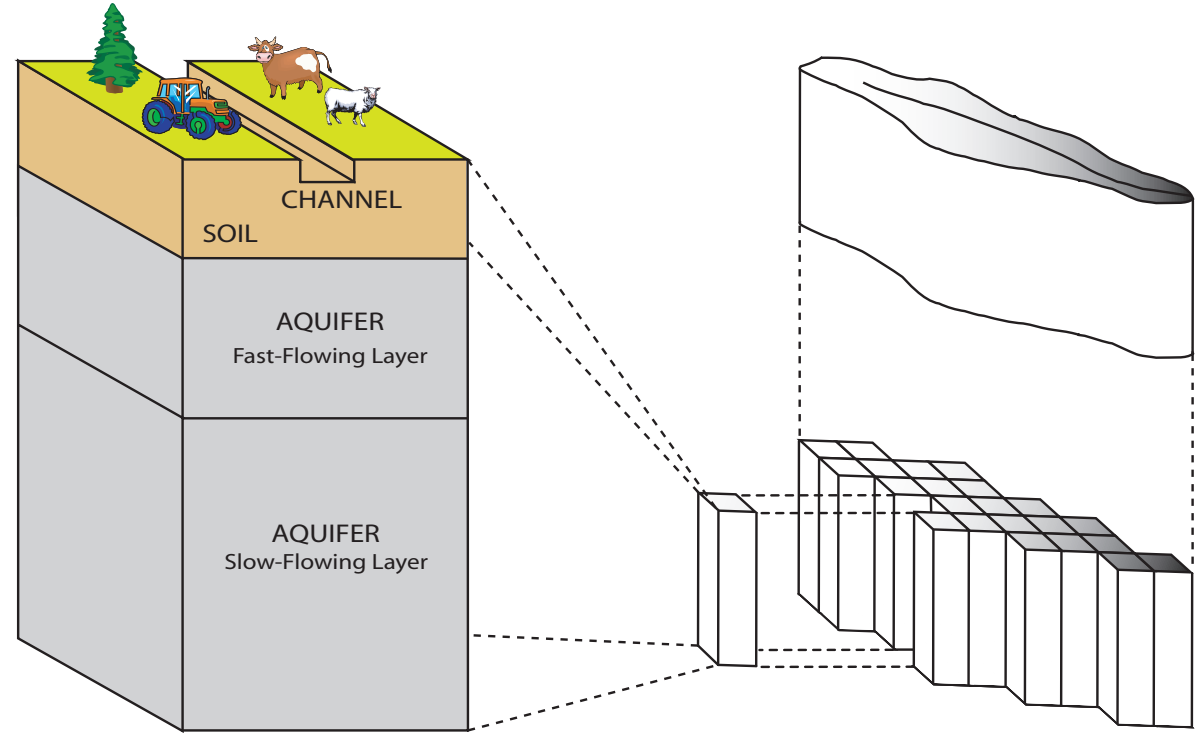

Fig. 1. Representation of a catchment in CAMEL. A catchment is represented using a network of square grid cells each of which represents the corresponding soil-aquifer column within the catchment. Based on this structure, the model simulates both surface and subsurface processes explicitly.

\section{A distributed continuous simulation model}

B. K. Koo et al.

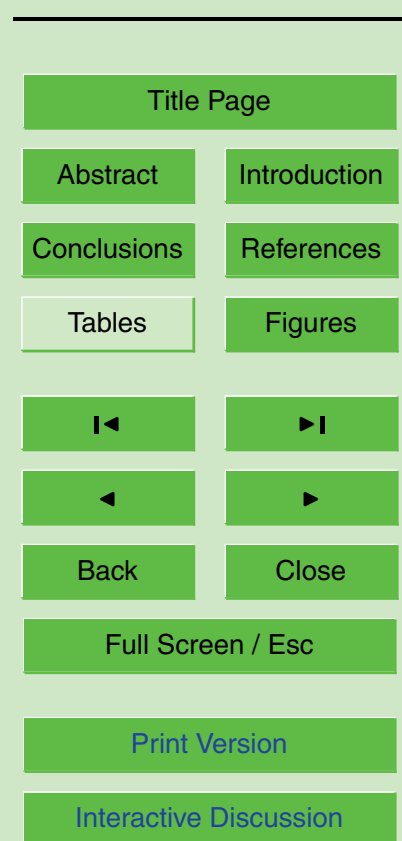

EGU 


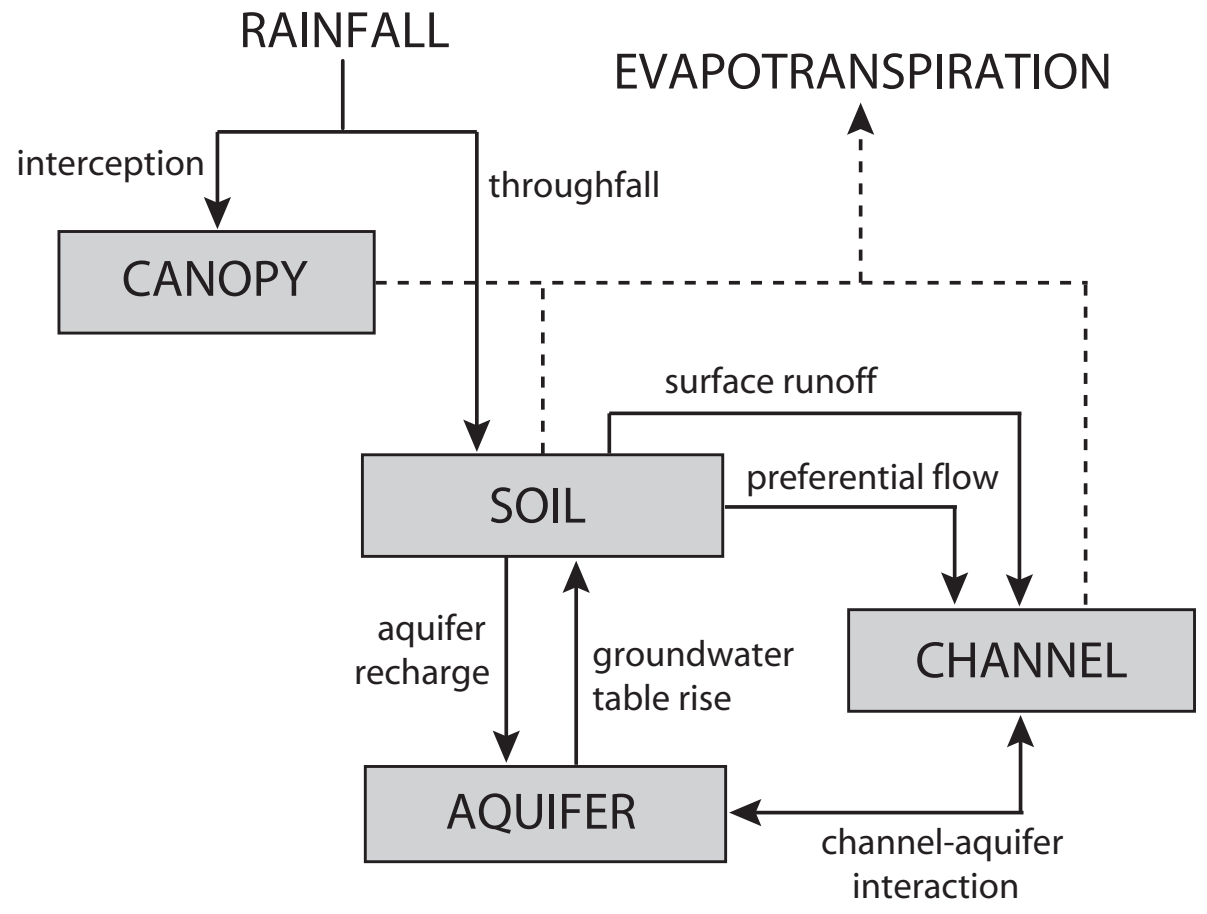

Fig. 2. Water storages and hydrological processes within a cell.

\section{A distributed continuous simulation model}

B. K. Koo et al.

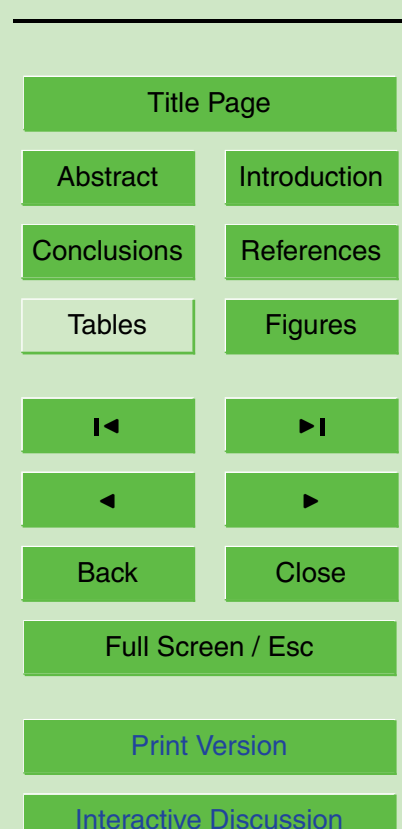

EGU 
(a)

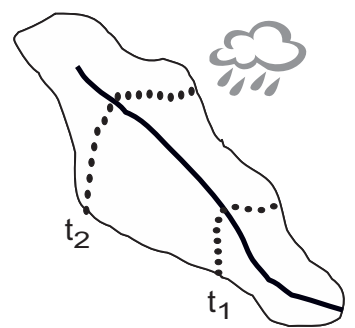

(b)

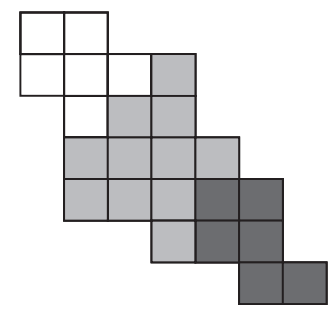

(c)

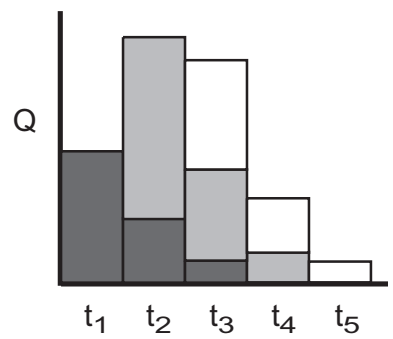

Fig. 3. Channel routing by a spatially distributed unit hydrograph approach: (a) a catchment can be divided into areas of isochrones; (b) isochrones are determined according to the mean travel time of channel water flows from a given cell to the catchment outlet; (c) unit hydrograph ordinates from individual isochrone areas are linearly superposed to estimate the total discharge.

\section{A distributed continuous simulation model}

B. K. Koo et al.

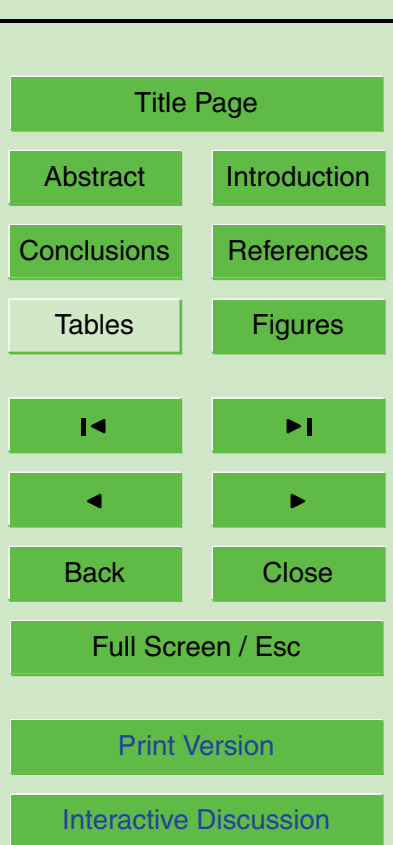

EGU 
$2,1359-1404,2005$

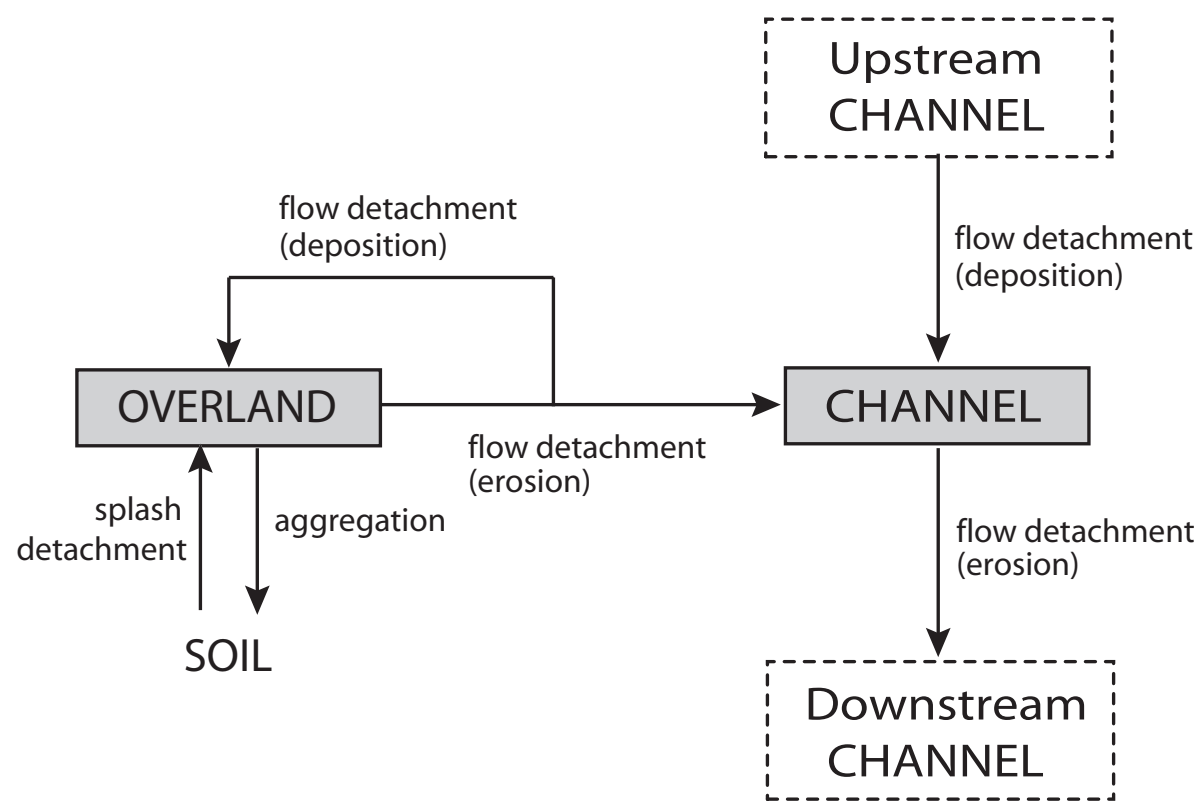

Fig. 4. Sediment storages and sediment transport processes within a cell. Sediment storages are defined for each of the four particle size classes, i.e. clay, silt, fine sand and coarse sand.

\section{A distributed continuous simulation model}

B. K. Koo et al.

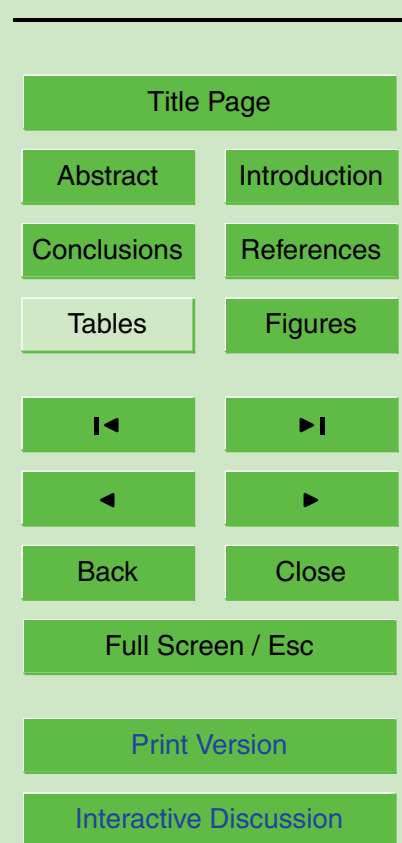

EGU 


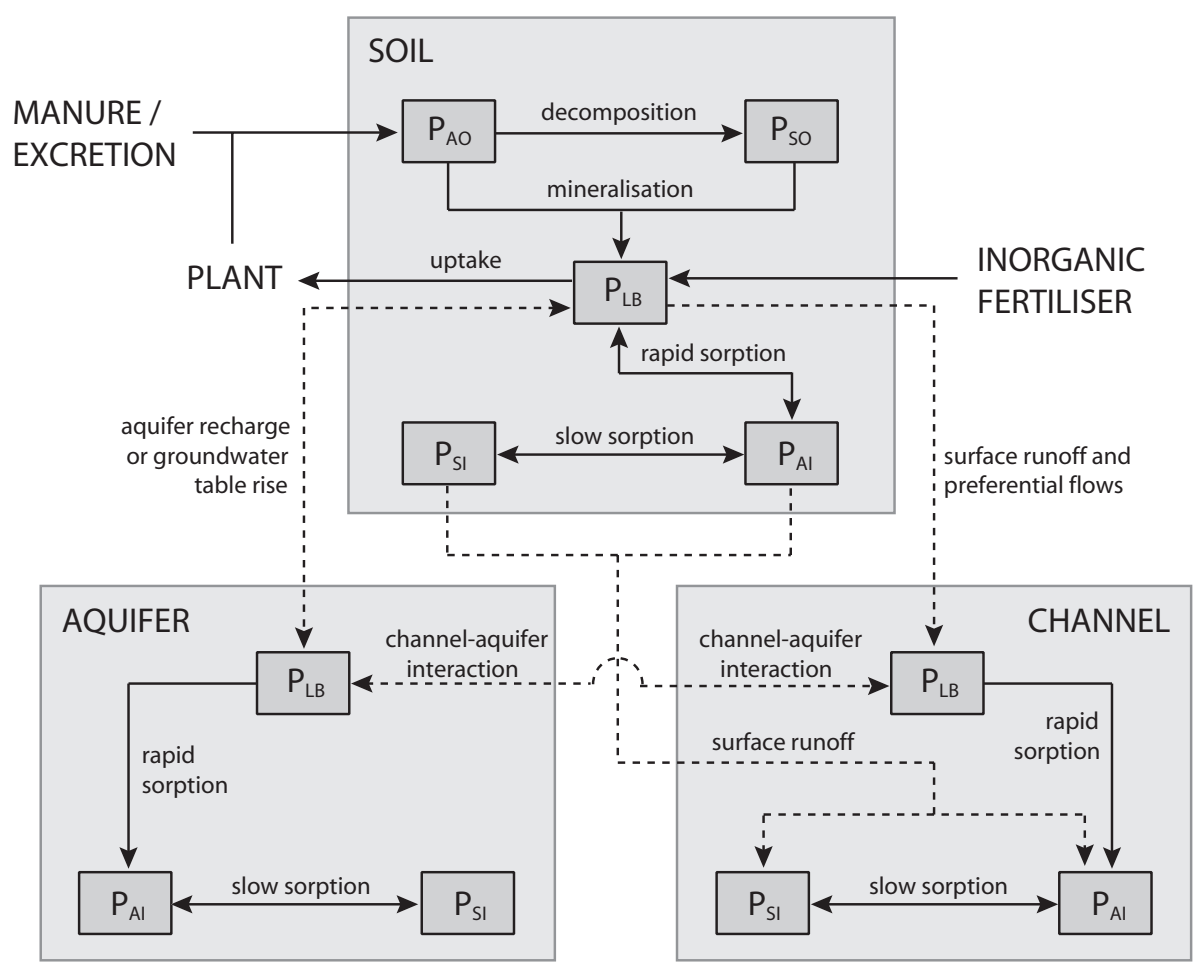

Fig. 5. Intra-cell $\mathrm{P}$ transformation and transport processes between $\mathrm{P}$ storages $\left(P_{A O}=\right.$ active organic $\mathrm{P} ; P_{S O}=$ stable organic $\mathrm{P} ; P_{L B}=$ labile $\mathrm{P} ; P_{A l}=$ active inorganic $\mathrm{P} ; P_{S l}=$ stable inorganic $\left.\mathrm{P}\right)$.

\section{A distributed continuous simulation model}

B. K. Koo et al.

\section{Title Page}

\begin{tabular}{|c|c|}
\hline Abstract & Introduction \\
\hline Conclusions & References \\
\hline Tables & Figures \\
\hline & \\
\hline & \\
\hline Back & Close \\
\hline
\end{tabular}

Full Screen / Esc

Print Version

Interactive Discussion 


\section{HESSD}

2, 1359-1404, 2005

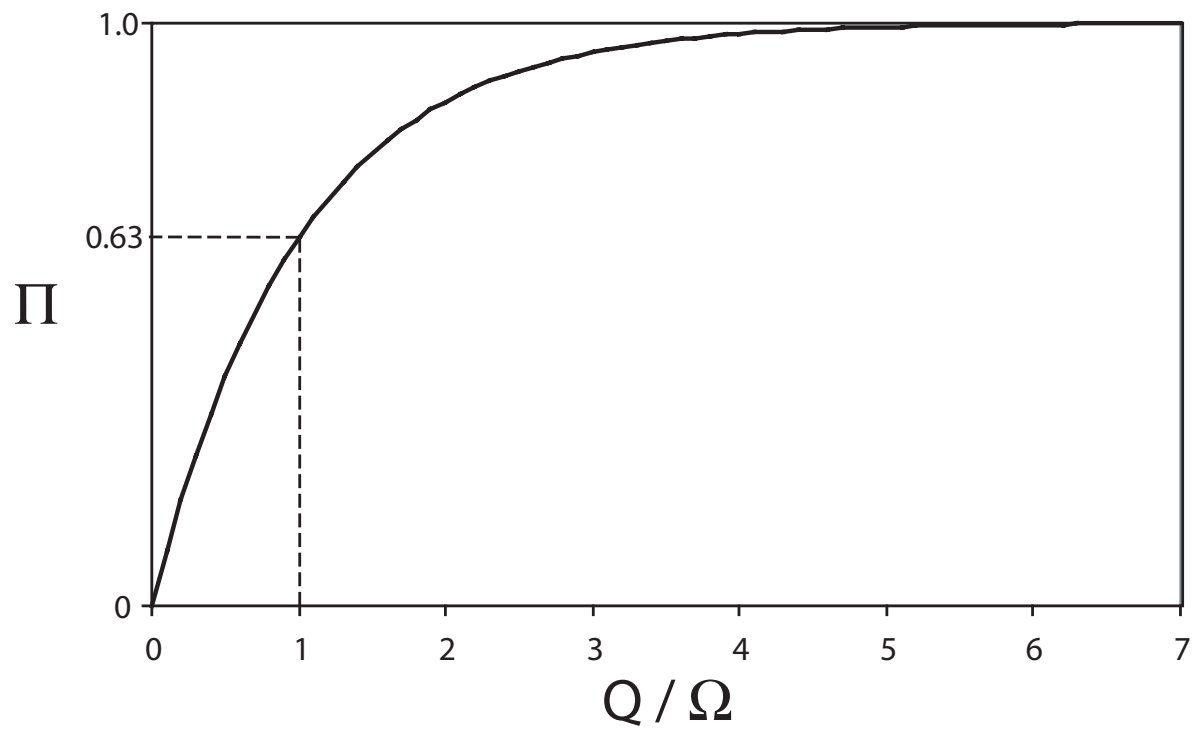

\section{A distributed continuous simulation model}

B. K. Koo et al.

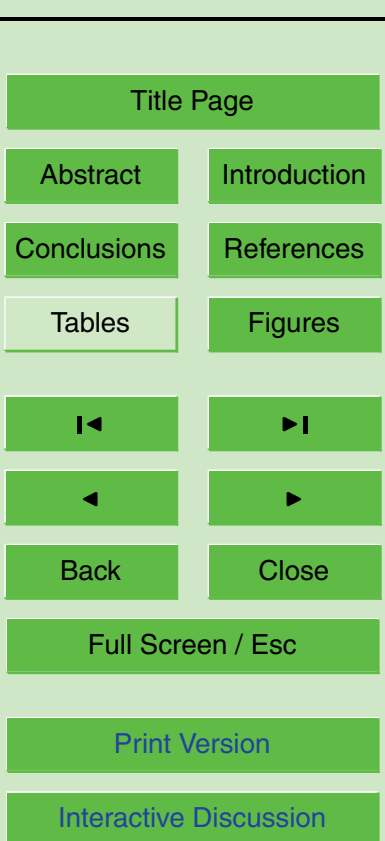

Fig. 6. A transfer function used in the model for estimating transport of dissolved P. When $Q=\Omega$, it is assumed that $63 \%$ of dissolved $\mathrm{P}$ in the "interactive zones" around the preferential pathways is transported. 